\title{
WHAT'S THE COST OF A FREE PASS? \\ A CALL FOR THE RE-ASSESSMENT OF STATUTES THAT ALLOW FOR THE ELIMINATION OF PERSONAL LIABILITY FOR DIRECTORS
}

\section{LLOYD L. DRURY, III*}

The tension between authority and accountability is central to corporate law. This tension stems from the fact that control of the corporation is vested in a board of directors, and board members take actions on behalf of those who have traditionally been considered the "owners" of the corporation, the shareholders. ${ }^{1}$ The separation of ownership from control is one of many factors that have allowed corporations to grow to the sizes they have reached today and to establish themselves as the dominant form of business organization. ${ }^{2}$ Corporations today are of a size and scope that is truly breathtaking. The largest corporation has a market capitalization of $\$ 472$ billion. ${ }^{3}$ Wal-Mart Stores, Inc. employs 1.9 million people worldwide. ${ }^{4}$ Google held its initial public offering of stock less than two years ago, ${ }^{5}$

* Visiting Professor, Loyola University New Orleans College of Law. I would like to thank Christine Hurt and everyone at The Conglomerate for hosting the 2007 Junior Scholars Workshop, where I presented an earlier version of this paper. I would also like to thank Matt Bodie, Lisa Fairfax, Elizabeth Nowicki, and especially Joan Heminway for their helpful comments.

1 See generally Adolph Berle \& Gardiner Means, The Modern Corporation And Private PROPERTY 66-111 (rev. ed. 1967) (discussing the evolution of control of the corporation). But cf. infra Part III.A (discussing contractarianism and espousing a theory of the firm in which shareholders merely supply one factor of production, the capital).

2 See Stephen M. Bainbridge, Corporation Law and Economics, 8-11 (Foundation Press 2002). Another major innovation of the business corporation is the limitation on personal liability of the shareholders.

3 This figure is for Exxon Mobil Corporation (XOM) based on an adjusted closing price of $\$ 82.93$ on May 21, 2007. Yahoo! Finance, http://finance.yahoo.com/q/hp?s=XOM (enter May 21, 2007 in date range).

4 WAL-MART STORES, INC., 2007 ANNUAL REPORT 6 (2007), available at http://walmartstores.com/Files/2007_annual_report.pdf.

5 Google's initial public offering occurred on August 19, $2004 . \quad$ Google, http://www.google.com/intl/en/corporate/history.html. 
and has grown to a market value of $\$ 108$ billion today. ${ }^{6}$ The corporate form has made all of this possible.

As much as the separation of ownership and control has aided the success of corporations, it has also introduced problems; specifically, it has introduced what economists call agency costs. Agency costs account for the fact that those making decisions on behalf of the corporation will not reap all of the rewards of those decisions. ${ }^{7}$ This divergence allows for the possibility that other incentives might cause board members to act in a manner that serves their personal interests at the expense of the corporation. ${ }^{8}$ The law has developed many mechanisms to monitor the performance of directors to ensure that the interests of directors and shareholders are aligned; foremost among these mechanisms is the imposition of fiduciary duties. ${ }^{9} \quad$ Generally, directors owe a duty of care and loyalty to shareholders. $^{10} \quad$ A duty of care requires that members of the board act as a reasonably prudent person would under similar circumstances. ${ }^{11}$ A duty of loyalty

6 This figure is based on an adjusted closing price of $\$ 470.60$ on May 21, 2007. Yahoo! Finance, http:/ / finance.yahoo.com/q/hp?s=GOOG (enter May 21, 2007 in date range).

7 See Michael C. Jensen \& William H. Meckling, Theory of the Firm: Managerial Behavior, Agency Costs and Ownership Structure, 3 J. FIN. ECON. 305 (1976).

8 See BERLE \& MEANS, supra note 1, at 112-16 (discussing "the divergence of interest between ownership and control").

9 See Charles M. Elson \& Robert B. Thompson, Van Gorkom's Legacy: The Limits of Judicially Enforced Constraints and the Promise of Proprietary Incentives, 96 Nw. U. L. Rev. 579, 581 (2002) (stating that "the most visible constraint in corporate law [is that] directors have common-law fiduciary duties, primarily of care and loyalty, in the decisions they make on behalf of the collective enterprise"). Fiduciary duties are not the only constraint on directors who seek to act contrary to the interest of shareholders. Id. Additional constraints include the markets, contracts and other private ordering, law, and norms. Id.

10 See id. Although most courts discuss the two duties of care and loyalty, some speak of the "triad" of duties-care, loyalty, and good faith. See infra Part II.C (discussing the ambiguity surrounding the duty of good faith).

11 R. Franklin Balotti \& Mark J. Gentile, Elimination or Limitation of Director Liability for Delaware Corporations, 12 DEL. J. CORP. L. 5, 15 (1987) (stating that the duty of care "requires that directors exercise diligence and care in managing the business and affairs of a corporation and exercise an informed business judgment in the discharge of their responsibilities"); Dennis R. Honabach, Smith $v$. Van Gorkom: Managerial Liability and Exculpatory Clauses-A Proposal to Fill the Gap of the Missing Officer Protection, 45 WASHBURN L. J. 307, 326 (2006) (stating that the duty of care requires a director "to act in good faith in what she reasonably believes to be in the best interest of the corporation using care that a person in like circumstances would reasonably exercise under similar circumstances”). 
2007] What's the Cost of a Free Pass? A CALl For the Re-Assessment of 101 STATUTES THAT ALLOW FOR THE ELIMINATION OF PERSONAL LIABILITY FOR DIRECTORS requires that directors make decisions solely for the benefit of the corporation, not with an eye to other interests or constituencies. ${ }^{12}$ Shareholders can enforce these duties by bringing civil suit to hold directors accountable for their actions. ${ }^{13}$

Because of this and other potential legal claims, members of a board of directors are faced with massive liability on a regular basis. ${ }^{14}$ Directors meet several times a year and make decisions at every meeting that entail significant financial consequences. If standards of simple negligence were applied to these decisions, as they are in a tort context, directors would face a very high risk of liability. There are many reasons why this result is unsatisfactory as a matter of policy. First, we are concerned about the ability of courts to identify a valid business decision. ${ }^{15}$ Second, we are concerned about "hindsight bias," the predilection of people to discount the soundness of a decision that has turned out poorly. ${ }^{16}$ Third, we are concerned about directors becoming unduly cautious for fear of incurring liability and, thus, refraining

12 Balotti \& Gentile, supra note 11, at 14 (stating that the duty of loyalty "requires that a director, in making a business decision, act in good faith and in the honest belief that the action taken is in the best interests of the corporation").

13 Elson \& Thompson, supra note 9, 581 (stating that directors' fiduciary duties "are usually enforced by shareholder-initiated derivative suits or class actions"). There is at least some debate on the centrality or effectiveness of the damages remedy. Compare Lisa M. Fairfax, Spare the Rod, Spoil the Director? Revitalizing Directors' Fiduciary Duty Through Legal Liability, 42 Hous. L. REV. 393, 395 (2005) (asserting "that legal liability represents an essential mechanism for ensuring directors' fidelity to their fiduciary duties") with Daniel R. Fischel \& Michael Bradley, The Role of Liability Rules and the Derivative Suit in Corporate Law: A Theoretical and Empirical Analysis, 71 CORNELL L. REV. 261, 263 (1986) (suggesting "that liability rules play a relatively minor role in assuring contractual performance by corporate managers in publicly held corporations").

14 Melvin Aaron Eisenberg, The Duty of Care of Corporate Directors and Officers, 51 U. PITT L. REV. 945, 970 (1990) (recognizing the potential for massive liability for directors). Actions under federal securities laws, even more than state law breach of duty claims, can be a concern to board members. Id.

15 The concern arises because judges and juries do "not have the experience of a board, they lack the awareness of the broad range of complex factors going into every business decision[,]" and “'hindsight bias' suggests that courts are much more likely to find a decision to have been ill-advised when they know that it turned out badly." Paula J. Dalley, The Business Judgment Rule: What You Thought You Knew, 60 CONSUMER FIN. L. Q. REP. 24, 25 (2006).

${ }^{16}$ Id. at 25; E. Norman Veasey \& Christine T. Di Guglielmo, What Happened in Delaware Corporate Law and Governance from 1992-2004? A Retrospective on Some Key Developments, 153 U. PA L. REV. 1399, 1424 (2005) (noting the prevalence of hindsight bias and "the human tendency to view decisions as having been obviously poor ones after having learned that the outcome was poor"). 
from taking risks that make good economic sense. ${ }^{17}$ These policy concerns have made the imposition of liability on directors for simple negligence undesirable.

Because of these concerns, the common law has developed a framework to protect directors from this type of liability. Specifically, directors' decisions are protected by the business judgment rule. ${ }^{18}$ The business judgment rule presumes that decisions are made in good faith, on an informed basis, and in what the directors reasonably believe is in the best interests of the corporation. ${ }^{19}$ Courts will not second-guess board decisions unless these presumptions are rebutted. ${ }^{20}$ Over time, courts have refined the workings of the rule, disallowing its application if a conflict of interest is present or if the board has simply failed to make a decision. ${ }^{21}$ This presumption assured board members that, absent a conflict of interest, their decision-making would be protected from scrutiny by courts after the fact. ${ }^{22}$

17 Id. at 1422 (recognizing that shareholders have an interest in ensuring that "the law does not encourage directors to be risk averse").

18 Stephen M. Bainbridge, The Business Judgment Rule as Abstention Doctrine, 57 VAND. L. REV. 83, 84 (2004) (asserting that the business judgment rule is designed to effect a compromise between authority and accountability, that is, "the need to preserve the board of directors decision-making discretion and the need to hold the board accountable for its decisions."); Dalley, supra note 15, at 25 (citing policy considerations in support of the business judgment rule including "an awareness of the limitations of courts ... to identify a valid business decision" and "the general interest of shareholders and the economy to encourage boards to take business risks").

${ }^{19}$ Lyman Johnson, The Modest Business Judgment Rule, 55 Bus. LAw. 625, 626 (2000). "The Delaware Supreme Court formulates the business judgment rule as 'a presumption that in making a business decision the directors of a corporation acted on an informed basis, in good faith and in the honest belief that the action taken was in the best interests of the company." Id. (quoting Aronson v. Lewis, 473 A.2d 805, 812 (Del. 1984)).

20 Johnson, supra note 19, at 627 (stating that if the shareholder plaintiff is unable to rebut the presumptions of the business judgment rule, then the rule will attach to protect the directors' decisions).

${ }^{21}$ See Charles Hansen, The ALI Corporate Governance Project: Of the Duty of Due Care and the Business Judgment Rule, A Commentary, 41 BUS. LAW. 1237, 1248-49 (1986) (recognizing three elements required for application of the business judgment rule: (1) that the director be disinterested in the transaction; (2) that the director's conduct is not egregious; and (3) that the director be independent such that he can exercise his judgment freely).

22 Tara L. Dunn, The Developing Theory of Good Faith in Director Conduct: Are Delaware Courts Ready to Force Corporate Directors to Go Out-of Pocket After Disney IV?, 83 DENV. U. L. REV. 531, 544 (2005) (asserting that " $[\mathrm{t}]$ he [business judgment] rule's presumption is so strong that when it applies, attacks on directors decision making are rarely successful”). 
2007] What's the Cost OF A FreE Pass? A CALl FOR THE Re-AsSESSMENT OF 103 STATUTES THAT ALLOW FOR THE ELIMINATION OF PERSONAL LIABILITY FOR DIRECTORS

The 1985 Delaware Supreme Court decision in Smith v. Van Gorkom ${ }^{23}$ caused considerable unrest among members of corporate boards and their legal advisors. ${ }^{24}$ In $V$ an Gorkom, board members were held personally liable for a breach of their fiduciary duties, despite the absence of a conflict of interest. ${ }^{25}$ Many observers were taken aback by this result, and a public outcry followed. ${ }^{26}$ The consequences of this decision, particularly the perceived crisis in securing directors' and officers' liability insurance, spurred some state legislatures into action. ${ }^{27}$ By 1986, Delaware enacted a statute enabling a corporation to limit or eliminate the personal liability of directors for breaches of the duty of care. ${ }^{28}$ All fifty states have implemented some version of

${ }^{23} 488$ A.2d 858 (Del. 1985).

24 See sources cited infra note 26.

25 Smith, 488 A.2d at 684, 873-893; Daniel R. Fischel, The Business Judgment Rule and the Trans Union Case, 40 BUS. LAw. 1437, 1437 (1985) (stating that the merger in Smith v. Van Gorkom "was negotiated at arm's length with no allegation that the decision of the directors of Trans Union was tainted by conflict of interest").

26 See, e.g., Fischel, supra note 25, at 1453-54 (discussing the "winners and losers" of Smith v. Van Gorkom); Morton Moskin, Trans Union: A Nailed Board, 10 DeL. J. CoRP. L. 405 (1985) (analyzing Smith v. Van Gorkom and concluding that the court clarified the standard directors are held to under the business judgment rule but did not narrow the scope of the rule, it only applies where directors are grossly negligent); Anthony Baldo, Delaware Rocks the Boat, FORBES, Apr. 8, 1985, at 126 (including Smith v. Van Gorkom, in a listing of "antimanagement rulings" issued by the Delaware Supreme Court); Charlie Blaine, Liability Looms for Firms' Boards, USA TODAY, Jan 31, 1986, at B6 (claiming that that Smith $v$. Van Gorkom was a catalyst in many directors asking to not be renominated and a reduction in insurance coverage for officers and directors); Arthur M. Borden, First Thoughts on Decision in Delaware on Trans Union, N.Y.L.J., Feb 25, 1985, at 1 (referring to the court's decision in Smith v. Van Gorkom as "baffling"); William B. Glaberson \& William J. Powell, Jr., A Landmark Ruling that Puts Board Members in Peril: They're Being Held Accountable-Even Financially-for Bad Corporate Decisions, Bus. WK., Mar. 18, 1985, at 56-57 (calling Smith v. Van Gorkom, a "harsh application of rules that traditionally protect the business judgments of corporate managers" and finding that the decision will be a "hot topic in boardrooms for years to come"); Leo Herzel, Scott J. Davis \& Dale Colling, Smith Brings Whip Down on Directors' Backs, Legal Times, May 13, 1985, at 14 (calling the decision of Smith v. Van Gorkom "dumbfounding"); Julie Rovner, $D$ \& O Indemnity: Discrete Contracts Seen as an Option, LEGAL TIMES, Nov. 25, 1985, at 1 (stating that Smith v. Van Gorkom has "contributed to the anxiety pervading many corporate board rooms").

27 See sources cited infra notes 28-29.

${ }^{28}$ Del. Code ANN. tit. 8, $\$ 102(b)$ (7) (2007); Honabach, supra note 11, at 307 ("Reacting to the alarms set off by [Smith v. Van Gorkom], the Delaware legislature quickly enacted section 102(b)(7) of the Delaware General Corporation Law. Section 102(b)(7) permits shareholders to adopt a charter provision granting directors immunity from personal liability for breaches of their duty of care."). 
Delaware's approach, and virtually all of the nation's largest corporations include these exculpatory provisions in their charters. ${ }^{29}$

This Article argues that the time has come to re-examine these statutes and improve the status quo. Part I describes the Smith v. Van Gorkom holding and the subsequent decision by the Delaware legislature to allow corporations to remove the prospect of personal liability for directors for duty of care breaches by adopting an exculpatory charter provision. Part II argues that the exculpatory statutes in their current form are harmful to shareholders and the orderly function of corporate law. First, this Part demonstrates that the existence and current use of the statute incentivizes board members to engage in sub-optimal behavior. Second, Part II questions the legitimacy of the original need for enacting the statute. Third, this Part claims that another area of corporate law, judicial interpretation of the duty of good faith, is being manipulated to circumvent the restrictions placed on courts by corporations that choose to eliminate liability for breaching the duty of care. Part III introduces the contractarian theory supporting of the current statute, examines the limitations of that theory, and explores the implications of the theory in determining the proper course of action. Finally, Part IV recommends actions available to dissatisfied shareholders, including a specific improvement in the mechanics of the statute-the addition of a requirement that shareholders must re-approve an exculpatory charter provision at least every five years.

\section{THE VAN GoRKom DECISION AND THE ENACTMENT OF SECTION 102(b)(7) IN DELAWARE}

Because of the important role that fiduciary duties play in holding directors accountable, the impetus to remove this protection needed to be significant. This motivation came from the confluence of a number of events, the most immediate of which was the 1985 Delaware Supreme Court decision in Smith v. Van Gorkom. ${ }^{30}$

\footnotetext{
29 Lawrence A. Hamermesh, Why I Do Not Teach Van Gorkom, 34 GA. L. REV. 477, 490 (2000) (revealing that in a sample "of one hundred 'Fortune 500' companies, ninety-eight of the stock corporations that incorporated in jurisdictions allowing for exculpatory charter provisions have adopted such provisions" and in "a sample of one hundred small- and midcapitalization companies, all but one (a Delaware corporation) of those incorporated in a jurisdiction authorizing exculpatory charter provisions have included such a provision in their articles or certificate of incorporation"); Honabach, supra note 11, at 307, 313 (claiming that following the enactment of section 102(b)(7) of the Delaware General Corporation Law, "all but one jurisdiction, the District of Columbia, enacted some kind of mandatory or optional provision permitting shareholders of corporations incorporated in their jurisdiction to provide similar protection to their directors" and "virtually every publicly traded corporation incorporated in Delaware adopted a section 102(b)7 provision").
}

30488 A.2d 858 (Del. 1985). 
2007] What's the Cost of a Free Pass? A CALL FOR THE RE-ASSESSMENT OF 105 STATUTES THAT ALLOW FOR THE ELIMINATION OF PERSONAL LIABILITY FOR DiRECTORS

Corporate attorneys had long believed that, even though both a duty of care and loyalty were owed to shareholders, the business judgment rule effectively precluded the imposition of personal liability on directors for a breach of the duty of care. ${ }^{31}$ In fact, a venerable statement of the law on this matter claimed that " $t$ t] cases in which directors of industrial corporations have been held liable in derivative suits for negligence uncomplicated by self-dealing is a search for a very small number of needles in a very large haystack. ${ }^{, 32}$ Absent a conflict, the standard advice was that directors need not worry about personal liability. ${ }^{33}$ V an Gorkom changed that advice. Following Van Gorkom, the Delaware legislature enacted section 102(b)(7) of the Delaware General Corporation Law allowing the elimination of personal liability for directors who breach their duty of care. ${ }^{34}$ This Part describes the Van Gorkom decision and traces the origins of the enactment of section 102(b)(7).

\section{A. Smith v. Van Gorkom}

Van Gorkom involved the sale of Trans Union Corporation. ${ }^{35}$ Jerome Van Gorkom was the Chief Executive Officer and a significant stockholder of Trans Union. $^{36}$ Van Gorkom discussed selling the company with some of his fellow executives, but only in a preliminary manner. ${ }^{37}$ As part of these discussions, officers of the company provided him with some basic financial data analyzing how easily a buyout could be financed. ${ }^{38}$ Using this information, Van Gorkom approached Jay

\footnotetext{
31 Thomas C. Lee, Comment, Limiting Corporate Directors' Liability: Delaware's Section 102(b)7 and the Erosion of the Directors' Duty of Care, 136 U. PA. L. REV. 239, 244, 246-47 (1987).

32 Joseph W. Bishop, Jr., Sitting Ducks and Decoy Ducks: New Trends in the Indemnification of Corporate Directors and Officers, 77 YALE L.J. 1078, 1099-1100 (1968).

${ }^{33}$ Honabach, supra note 11, at 321 (stating that "before Van Gorkom, no one thought directors faced any real threat of liability for breaching their duty of care").

34 DeL. CODE ANN. tit. 8, \ 102(b)(7) (2007).

35 Technically, the case involved a cash-out merger of Trans Union into New T Company, a whollyowned subsidiary of Marmon Group, Inc. Smith, 488 A2.d at 863.

${ }^{36} I d$. at $865-66$.

${ }^{37}$ Id. at 865 .

${ }^{38} I d$.
} 
Pritzker about buying the company. ${ }^{39}$ Pritzker offered to purchase Trans Union and gave Van Gorkom a short timeframe during which to respond to his proposal. ${ }^{40}$

Van Gorkom called a meeting of the Trans Union board to discuss the acquisition proposal. ${ }^{41}$ The meeting was called on only two days notice, and no indication of its purpose was given in advance. ${ }^{42}$ Although Van Gorkom gave an oral presentation at the meeting, he did not provide financial analyses or any written documentation and did not disclose the source of his figures or the full extent of the negotiation process by which Pritzker became interested in purchasing Trans Union. $^{43}$ The board asked very few follow-up questions before approving the merger. $^{44}$ Van Gorkom then executed the Merger Agreement with substantial amendments on behalf of Trans Union without seeking further board approval. ${ }^{45}$

Delaware's Supreme Court found that the board's actions violated the duty of care and that the board acted in a grossly negligent manner in deciding to accept Pritzker's offer. ${ }^{46}$ The court based its conclusion on the finding that the board did not act on an informed basis when making its decision to proceed with the acquisition. $^{47}$ Prior to the Van Gorkom holding, courts did not find directors

\footnotetext{
${ }^{39}$ Id. at 866.

${ }^{40}$ Id. 867.

${ }^{41} I d$.

${ }^{42} I d$.

${ }^{43}$ Id. at 868 .

${ }^{44}$ Id. at 869.

${ }^{45} I d$.

${ }^{46}$ Id. at $872-73,874$.
}

${ }^{47}$ Id. at 874; Dierdre A. Burgman \& Paul N. Cox, Corporate Directors, Corporate Realities and Deliberative Process: An Analysis of the Trans Union Case, 11 J. CORP L. 311, 317, 332 (1986) (stating "that the Trans Union directors . . . were not entitled to the presumption of the business judgment rule because their decision was not informed" and that the case "establish[ed] that there is a minimum standard of information gathering that all of the Trans Union directors failed to meet”). 
2007] What's the Cost of A Free Pass? A CALl For the Re-Assessment OF 107 STATUTES THAT ALLOW FOR THE ELIMINATION OF PERSONAL LIABILITY FOR DIRECTORS personally liable absent a conflict of interest. ${ }^{48}$ However, in Van Gorkom, the court found the directors liable based solely on the breaches of the duty of care. ${ }^{49}$

This reliance on the duty of care alone instigated fears and concerns from many quarters. First, commentators were unsure whether $V$ an Gorkom signaled a change in the law that would mean the beginning of intense scrutiny of the substance of all board decisions. ${ }^{50}$ The decision also brought about concern that the protections of the business judgment rule would be meaningless if courts were to entertain substantive doubts about the wisdom of board decisions based on the informational component of the duty of care. ${ }^{51}$ Other commentators, while not believing that $V$ an Gorkom changed the substantive legal standards, viewed the case as an unprecedented application of those strict standards. ${ }^{52}$

Not everyone was shocked or surprised by Van Gorkom. While the popular press ran several stories expressing dismay over the result, ${ }^{53}$ the academic commentary was less uniform in their analysis. There were certainly articles critical

48 Honabach, supra note 11, at 321 ("It is true that before Van Gorkom, no one thought directors faced any real threat of liability for breaching their duty of care.”).

49 Burgman \& Cox, supra note 47, at 312 (naming Smith v. Gorkom as "the principal modern case imposing director liability in a context not involving a breach of the duty of loyalty[,]" a conclusion that "sent shock waves through the corporate bar").

50 See Leo Herzel \& Leo Katz, Smith v. Van Gorkom: The Business of Judging Business Judgmnent, 41 Bus. LAW. 1187, 1188 (1986) (stating that "the court's decision seemed misguided and Trans Union's actions entirely proper"); Fred S. McChesney, A Bird in the Hand and Liability in the Bush: Why Van Gorkom Still Rankles, Probably, 96 Nw. U. L. REV. 631, 631, 648 (2002) (calling the case "a legal disaster" and noting that it hurt the ability of corporations to attract directors to their boards and retain existing directors).

${ }^{51}$ Herzel \& Katz, supra note 50, at 1189.

${ }^{52}$ See Michael Bradley \& Cindy A. Schipani, The Relevance of the Duty of Care Standard in Corporate Governance, 75 IOWA L. REV 1, 42 (1989) (noting that, before Smith v. Van Gorkom, "courts rarely found directors grossly negligent" absent a finding of absolute neglect, but suggesting that the Smith decision tightened the legal constraints on directors); Sean J. Griffith, Good Faith Business Judgment: A Theory of Rhetoric in Corporate Law Jurisprudence, 55 DUKE L.J. 1, 14 (2005) (recognizing that most commentators agree that "the evidence does not support the conclusion that the Trans Union board had been grossly negligent" but rather that "that courts used Trans Union in order to have a voice in corporate governance notwithstanding the supposed constraint of the business judgment rule”).

53 See sources cited supra note 26. 
of the decision, ${ }^{54}$ but many did not find fault. Some commentators noted that $V$ an Gorkom placed an increased emphasis on the informational component of decisionmaking but did not alter pre-existing legal standards. ${ }^{55}$ Others argued that the import of the holding was limited to the facts of the case. ${ }^{56}$ Still other commentators found nothing more than a straightforward application of existing precedent. ${ }^{57}$ The discussion about the import and proper place of $\operatorname{Van}$ Gorkom continues today. ${ }^{58}$

Regardless of whether the agonizing over Van Gorkom was justified, the directors' and officers' insurance market sought to immediately incorporate the import of the decision into its underwriting practices. ${ }^{59}$ Serious concerns over the potential for increased liability arose in the insurance market from those providing

54 See sources cited supra notes 50, 52 .

55 Steven F. Mones, Comment, Mining the Safe Harbor? The Business Judgment Rule after Trans Union, 10 DEL. J. CORP. L. 545, 559, 567-68 (1985) (citing "the major impact of Trans Union" is its message that corporate directors may be held personally liable based solely on not being thoroughly informed before making business decisions, but noting that, as a legal matter, "[ $\mathrm{t}]$ he Trans Union decision does not alter the legal standard by which directors' duty of care is measured”); see also Charles Hansen, supra note 21, at 1242 (stating that "Smith v. Van Gorkom strongly confirms that the standard [of due care] is process-oriented"); Thomas C. Wagner, Note, Corporate Law-The Business Judgment Rule Imposes Procedural Requirements on Corporate Directors-Smith v. Van Gorkom, 488 A.2d 858 (Del. 1985), 14 FLA. ST. U. L. REV. 109, 119 (1986) (claiming that Trans Union is "a clarification of the existing due care requirement, rather than an erosion of the rule's protection").

56 William T. Quillen, Trans Union, Business Judgment, and Neutral Principles, 10 DEL. J. CoRP. L. 465, 466, 469-70 (1985) (claiming that Trans Union is heavily fact based, reinforces the importance of the process of decision making, and has little lasting legal significance); Herbert S. Wander \& Alain G. LeCoque, Boardroom Jitters: Corporate Control Transactions and Today's Business Judgment Rule, 42 Bus. LAW. 29, 39 (1986) (asserting that "the decision appears to be correct and its outcome not surprising" even though it has been "sharply attacked").

${ }^{57}$ Barry F. Schwartz \& James G. Wiles, Trans Union: Neither New' Law Nor 'Bad' Law, 10 DEL. J. CORP. L. 429, 444 (1985) (finding "no basis for concluding that Trans Union undermines ... well-established precedents”); Patricia Daniel, Special Project Note, Recent Developments Concerning the Duty of Care, the Duty of Loyalty, and the Business Judgment Rule, 40 VAND L. REV. 631, 633 (1987) (concluding "[r]ecent Delaware state court decisions do not significantly change traditional corporate law ...."); Honabach, supra note 11, at 321 (reasoning "that Van Gorkom threatened liability only if directors failed miserably in following an appropriate decision-making procedure like that outlined in the decision.").

58 See, e.g., Symposium, Van Gorkom and the Corporate Board: Problem, Solution, or Placebo?, 96 Nw. U. L. REV. 449 (2002); Symposium, The Smith v. Van Gorkom Symposium, 45 WASHBURN L.J. 267 (2006).

${ }^{59}$ Balotti, supra note 11 , at 8-9. 
2007] What's the Cost of a Free Pass? A CALl For THE RE-ASSESSMENT OF 109 STATUTES THAT ALLOW FOR THE ELIMINATION OF PERSONAL LIABILITY FOR DIRECTORS

insurance as well as the directors seeking to be insured. ${ }^{60}$ Some directors resigned from their posts while others refused to consider board service. ${ }^{61}$ Because of this inhospitable climate and the uncertainty surrounding the $V$ an Gorkom decision, the price of coverage increased substantially, and some boards were unable to secure adequate coverage at any price. ${ }^{62}$

\section{B. Elimination of Personal Liability-The Enactment of Section 102(b)(7)}

This unsettled situation, particularly in the insurance market, led state legislatures to act. ${ }^{63}$ Delaware, home of Smith v. Van Gorkom, was one of the first to act, and this Article will focus on Delaware's response. ${ }^{64}$ Delaware enacted section

${ }^{60} I d$. (discussing the background in which insurance costs increased surrounding uncertainty in the extent of director liability). But see Honabach, supra note 11, at 322 (claiming that "despite the hysteria of the moment, directors were no more at risk after Van Gorkom than they ever were before" and identifying the effect of Delaware Code Annotated title 8, section 107(b)(7) as psychological rather than legal); Wagner, supra note 56, at 122 (finding that "the paranoia of the business community over the potential effects of [Smith v. Van Gorkom] has led to consequences out of proportion to the decision's importance.").

${ }^{61}$ Balotti \& Gentile, supra note 11, at 9 (claiming that "[m]any directors have resigned from their positions or have declined to seek to renew their terms as such when liability insurance is unavailable, and many qualified individuals have refused to accept directorships initially."); Lee, supra note 32, at 241, 256-57 (asserting that many qualified directors "have fled corporate boardrooms in search of greener and safer pastures" and that "[t]he Delaware legislature was faced with the real problem of director resignations or refusals to serve"); E. Norman Veasey, Jesse A. Finkelstein, \& C. Stephen Bigler, Delaware Supports Directors with a Three-legged Stool of Limited Liability, Indemnification, and Insurance, 42 Bus. LAw. 399, 401 (1987) (noting that "if competent directors are not willing to serve . . the laudable policy of having independent directors as decisionmakers is seriously undermined").

62 But see Honabach, supra note 11, at 324 (asserting that "for reasons only tangentially related to Van Gorkom, D\&O insurance rates began to soar"); Lee, supra note 31, at 252-54 (finding that "[although almost all would agree that the general insurance crisis is a problem deeply rooted in our society, less agreement exists regarding the causes of the crisis[,] but acknowledging that "some evidence does exist, however, that a good deal of the insurance industry's woes were self-inflicted through competitive underpricing and questionable management").

${ }^{63}$ Bradley \& Schipani, supra note 52 at 43 (citing legislative history referring to the "concern regarding changes in the market for directors" liability insurance[]" which "resulted in the unavailability of D\&O liability insurance" and the unwillingness of many to serve as directors); Daniel, supra note 57, at 661 (noting significant modifications in some state corporation statutes instituted in response to "the increasing liability of directors and officers" coupled with "the decreasing availability of D\&O liability insurance").

${ }^{64}$ This Article focuses on Delaware's response to Van Gorkom. In addition to being the jurisdiction where Smith v. Van Gorkom was decided, Delaware's response is particularly fitting to follow for at least two other reasons. First, Delaware is home to a large number of the nation's largest 
102(b)(7) of its General Corporation Law allowing corporations to include a provision in their charter that either limits or eliminates personal liability of directors for the breach of their fiduciary duties. ${ }^{65}$ The full text reads:

(b) In addition to the matters required to be set forth in the certificate of incorporation by subsection (a) of this section, the certificate of incorporation may also contain any or all of the following matters:

(7) A provision eliminating or limiting the personal liability of a director to the corporation or its stockholders for monetary damages for breach of fiduciary duty as a director, provided that such provision shall not eliminate or limit the liability of a director: (i) [f]or any breach of the director's duty of loyalty to the corporation or its stockholders; (ii) for acts or omissions not in good faith or which involve intentional misconduct or a knowing violation of law; (iii) under $\int 174$ of this title; or (iv) for any transaction from which the director derived an improper personal benefit. No such provision shall eliminate or limit the liability of a director for any act or omission occurring prior to the date when such provision becomes effective. All references in this paragraph to a director shall also be deemed to refer ( $\mathrm{x}$ ) to a member of the governing body of a corporation which is not authorized to issue capital stock, and (y) to such other person or persons, if any, who, pursuant to a provision of the certificate of incorporation in accordance with $\int 141$ (a) of this title, exercise or perform any of the powers or duties otherwise conferred or imposed upon the board of directors by this title. ${ }^{66}$

corporations. Veasey \& Di Guglielmo, supra note 16, at 1403 (finding that, as of February 19, 2004, "[n] early sixty percent of the Fortune 500 companies and nearly the same proportion of those listed on the New York Stock Exchange are Delaware corporations. . . . [and] seventy percent of initial public offerings in 2004 on the New York Stock Exchange, the American Stock Exchange, and the NASDAQ were Delaware corporations"). Second, many states followed Delaware's approach or a close variation to it. Honabach, supra note 11, at 314 (discussing exculpatory provisions and stating that "[t]he Delaware model remains dominant").

${ }^{65}$ DeL. Code ANN. tit. 8, \ 102(b)(7) (2007); Honabach, supra note 11, at 307.

${ }^{66}$ DEL. CODE ANN. tit. 8, $₫ 102(b)(7)$. 
2007] What's the Cost of a Free Pass? A CALl FOR the RE-ASSESSMENT OF 111 STATUTES THAT ALLOW FOR THE ELIMINATION OF PERSONAL LIABILITY FOR DIRECTORS

As is clear from the text, not all breaches are excusable. ${ }^{67}$ The statute expressly prohibits the elimination of liability for a breach of the duty of loyalty, declaration of illegal dividends, acts known to be unlawful or not taken in good faith, and transactions in which a director derives an improper personal benefit. ${ }^{68}$

In essence, this statute allows exculpation for breaches of the duty of care, including the type that occurred in Van Gorkom. ${ }^{69}$ In fact, the statutory amendment is widely seen as legislatively overturning the decision. ${ }^{70}$ Those in favor of the statute pointed to policy justifications for its enactment, similar to those supporting the business judgment rule. ${ }^{71}$ Those opposed felt that the legislature abdicated its role in ensuring effective corporate governance. ${ }^{72}$ Regardless of their views on the

${ }^{67}$ Id.; Honabach, supra note 11, at 312 (stating that section 102(b)(7) allows corporations "to shelter directors from personal liability to the corporation or its shareholders as long as their conduct does not fall within four express exception").

${ }^{6}$ DEL. CODE ANN. tit. 8, \102(b)(7); Honabach, supra note 11, at 312 (citing the four exceptions as "unlawful dividends; acts or omissions that constitute a breach of the director's duty of loyalty; acts or omissions not made in good faith or which involve intentional misconduct or a knowing violation of law; and any transaction from which the director derives an improper personal benefit").

${ }^{69}$ Honabach, supra note 11, at 312 ("Section 102(b)(7) allows corporations to negate the application of Van Gorkom to their directors even when directors engage in grossly negligent conduct . . ..”).

${ }^{70}$ Griffith, supra note 52, at 63 (claiming that, "[w]ith the adoption of $\int 102(\mathrm{~b})(7)$ of the Delaware General Corporation Law, the management lobby won an amendment effectively overturning [Smith v. Van Gorkom]").

${ }^{71}$ Eisenberg, supra note 14, at 970-71 (arguing that "[ $\mathrm{t}$ ] he concept of limiting the liability of directors for violations of the duty of care that do not involve a lack of good faith or willful misconduct is appealing[" in light of the potential for massive liability, the difficulty in attracting qualified candidates, and the desire to avoid undue risk aversion); Fischel \& Bradley, supra note 13, at 284 (stating that "[c]orporate law provides firms with broad flexibility in deciding whether to provide indemnification or insurance to managers"); James J. Hanks, Jr., Evaluating Recent State Legislation on Director and Officer Liability Limitation and Indemnification, 43 BUS. LAW. 1207, 1207 (1988) ("One of the principal themes of corporate governance in the second half of [the 1980s was] protection of corporate directors and officers from personal liability for money damages.”).

72 Hillary A. Sale, Delaware's Good Faith, 89 CORnell L. REV. 456, 458 (2004) (arguing that the Delaware legislature "abdicated part of its role in regulating corporate governance [by] adopting the now ubiquitous exculpatory statute that allows companies, at the directors' initiative to exempt themselves from damages for failing to adhere to their duty of care"). 
soundness of the amendment, commentators agree that section 102(b)(7) effectively eliminated director liability for a duty of care breach similar to that in Van Gorkom. ${ }^{73}$

There are two particularly noteworthy aspects of the mechanics of section 102(b)(7). First, it is placed in the section of the General Corporation Law that lists permissive charter provisions. ${ }^{74}$ Thus, section 102(b)(7) is a "charter option" statute, an elective remedy for corporations and not a mandatory rule. ${ }^{75}$ The exculpatory provision is not forced on any shareholders, and it must either be part of the charter when a shareholder first invests or the shareholders must affirmatively vote to include it. $^{76}$ Second, section 102(b)(7) only eliminates personal liability for directors. ${ }^{77}$ Equitable remedies, such as securing an injunction, remain available for a breach of the duty of care. ${ }^{78}$ This approach has been very widely adopted, and each

73 Elson \& Thompson, supra note 9, at 583 (claiming "Delaware's quick enactment of section 102(b)(7) reversed much of the substantive liability impact of the decision in Van Gorkom, so that directors today doing what the Trans Union directors did would not be subject to liability for damages"); Hamermesh, supra note 29, at 479 (minimizing the significance of Smith v. Van Gorkom because "[e]xculpatory charter provisions adopted pursuant to statutes, almost universally enacted since Van Gorkom, have rendered the damages claim for breach of the duty of care essentially nonexistent").

${ }^{74}$ DEL. CODE ANN. tit. 8, $\$ 102(b) (2007) ("In addition to the matters required to be set forth in the certificate of incorporation . . . the certificate of incorporation may also contain any or all of the following matters ....').

75 Hanks, supra note 71, at 1210, 1216 (finding that the charter option statute for director liability is much more popular than the more radical approach of self-executing statutes); James J. Hanks, Jr. \& Larry P. Scriggins, Protecting Directors and Officers From Liability-The Influence of the Model Business Corporation Act, 56 Bus. LAW. 3, 24 (2000) (outlining the two principal statutory approaches that emerged: (1) charter option provisions which gives the corporation the option of including a provision in the charter that eliminates or limits the personal liability of its directors subject to expressly stated exceptions and (2) self-executing provisions which is a "direct legislative immunization of directors . . . from liability, without the necessity of a charter provision, but with certain exceptions").

${ }^{76}$ Hanks \& Scriggins, supra note 75, at 24 (stating that the charter option authorizes a corporation to include a provision either eliminating or limiting director liability in its charter either when it is "originally adopted or by amendment (thus requiring a shareholder vote)").

77 DEL. CODE ANN. tit. 8, S 102(b) (2007) (“A provision eliminating or limiting the personal liability of a director to the corporation or its stockholder for monetary damages for breach of fiduciary duty as a director....") (emphasis added).

78 Balotti \& Gentile, supra note 11, at 15 ("Directors' conduct in meeting the duty of care under section 102(b)(7) is still subject to equitable remedies, such as injunctive or rescissory relief . . ..”); 
2007] What's the Cost of a Free Pass? A CALL For THE RE-ASSESSMENT OF 113 STATUTES THAT ALLOW FOR THE ELIMINATION OF PERSONAL LIABILITY FOR DiRECTORS of the fifty states has adopted some version of the statute. ${ }^{79}$ In addition, virtually every major corporation has included a broad provision eliminating liability in their charters. ${ }^{80}$

\section{Problems with the Status Quo}

The current status quo is that directors of most companies have essentially no risk of being held liable for breaching their duty of care. ${ }^{81}$ Many favor the statutes, and their arguments mimic those in favor of the business judgment rule. First, courts are poorly situated and trained to make determinations about the propriety of business decisions. Second, looking at spur of the moment decisions with the benefit of hindsight unfairly prejudices courts against those decisions that turn out poorly despite having been initially made properly. Directors who know that a risky decision that later turns out poorly could cost them their entire personal net worth may be unduly cautious in their choices. ${ }^{82}$

Whatever its benefits, the status quo promotes unsatisfactory results in at least three ways. First, the statute gives directors incentives to be negligent in handling the affairs of the corporation. ${ }^{83}$ Second, later evidence has called into question the original need for the statute. ${ }^{84}$ Third, because of the unavailability of the duty of care in most cases, courts are expanding the notion of the duty of good faith to encompass breaches that appear to be facially indistinguishable from violations of the duty of care. ${ }^{85}$

\footnotetext{
Veasey, Finkelstein, \& Bigler, supra note 61, at 403 ("The duty of care continues to have vitality in remedial contexts as opposed to actions for personal monetary damages against directors as individuals.").

79 See text accompanying supra, notes 29, 64.

${ }^{80} I d$.

81 See supra notes 69-73 and accompanying text.

${ }^{82}$ Herzel \& Katz, supra note 50, at 1189 (stating that " $[\mathrm{t}]$ he threat of crushing legal liability will make [directors] too cautious").

83 See infra Part II.A.

${ }^{84}$ See infra Part II.B.

85 See infra Part II.C.
} 


\section{A. Section 102(b)(7) Provides Directors Incentives to Be Negligent}

The first problem with the current statutory structure is that it incentivizes directors toward sub-optimal behavior. The statute does this in both an obvious and a subtle way. Obviously, if a corporation enacts a charter amendment, as allowed in section 102(b)(7), there is virtually no chance that a director will sustain any personal financial penalty for a duty of care breach. ${ }^{86}$ Without this fear of personal sanction, the deterrent effect of a duty of care violation is taken away. In general, negative consequences provide an incentive to avoid certain types of behavior. The threat of sanction for acting in a grossly negligent manner serves this purpose. Second, a subtler, more insidious way that the law incentivizes directors to be careless is seen with the interplay between state corporate law and federal securities laws, particularly private rights of action under Rule 10b-5 of the Securities and Exchange Commission. Rule 10b-5 actions require scienter and impose liability only when the defendant acts knowingly and with intent to deceive. ${ }^{87}$ Thus, this standard imposes liability on active, engaged board members who uncover material misstatements or omissions but do not act emphatically enough to prevent them. However, a lax or unengaged board member does not act with scienter and, therefore, will not incur the same liability under Rule 10b-5.

\section{The Importance of Personal Liability}

Many commentators have stressed the importance of the deterrent effect of liability rules in general, and especially in the duty of care context. ${ }^{88}$ In Delaware's Good Faith, Professor Hillary Sale attributes the potential for liability as central in creating a norm of good corporate governance and an incentive for boards to avoid penalty. ${ }^{89}$ She further suggests that adherence to the norm of due care makes

${ }^{86}$ Dunn, supra note 22, at 544 n.65 (quoting In re Caremark Int'l Inc. Derivative Litig., 698 A.2d 959, 967 (Del. Ch. 1996)) (stating that a duty of care claim "is possibly the most difficult theory in corporation law upon which a plaintiff might hope to win a judgment").

87 Ernst \& Ernst v. Hochfelder, 425 U.S. 185, 193 (1976) (holding that action under Rule 10b-5 requires scienter and describing scienter as an "intent to deceive, manipulate, or defraud").

${ }^{88}$ Lee, supra note 31, at 264, 267 (defining the duty of care today as “an obligation to 'show up' and inform oneself, and not much else[,]" yet concluding that the "duty of care has always served, and will continue to serve, an important deterrent function-broadly as an 'aspirational statement' and narrowly as a remedial tool when other marketbased deterrents have failed.").

89 Sale, supra note 72, at 466 (finding a roadmap in Van Gorkom for duty of care enforcement: "imposition of substantial personal liability on the fiduciaries involved in the challenged decision ... creat [es] an incentive for other fiduciaries to avoid such penalties and adhere to the norms of good corporate governance"). 
2007] What's the Cost of A Free Pass? A CALl For the Re-AsSESSMENT OF 115 STATUTES THAT ALLOW FOR THE ELIMINATION OF PERSONAL LIABILITY FOR DIRECTORS

directors less likely to violate other duties. ${ }^{90}$ The idea is that the procedural good of informing oneself is not simply an intrinsic good, but is instrumental in achieving other desirable ends such as being aware of conflicts and making substantive decisions that are more likely to be of the greatest benefit to shareholders. In a similar vein, Professor Lynn Stout argues that the requirement to become informed may be critical in promoting the behavior that is most beneficial to the firm and its shareholders by reducing the marginal personal sacrifice that a director must make to act in such a careful manner. ${ }^{91}$ In addition, Mae Kuykendall points to exculpation statutes as causing a separation of the substantive law of corporations and the remedies available to redress violations of those substantive provisions. ${ }^{92}$ Each of these commentators, in a similar yet distinct way, argues for the importance of a robust duty of care, bolstered by the potential for sanction.

However, other commentators have argued that either other checks on director behavior adequately contain this externality or that the inclusion of the charter amendment does little to alter the current landscape. ${ }^{93}$ The checks most frequently cited as compensating for the lack of personal liability are market forces and reputational concerns. ${ }^{94}$ Market forces impact director behavior in two different ways. First, shareholders are less likely to re-elect directors who do not help the corporation become more valuable. ${ }^{5}$ This linkage provides directors with an

${ }^{90} \mathrm{Id}$. at 465 ("Directors and officers who comply with the duty of due care are less likely to violate other duties. They are more likely to weigh decisions, consult with appropriate advisors, and disclose conflicts of interest.").

${ }^{91}$ Lynn A. Stout, In Praise of Procedure: An Economic and Behavioral Defense of Smith v. Van Gorkom and the Business Judgment Rule, 96 Nw. U. L. Rev. 675, 678 (2002) (suggesting that requiring directors to be informed before they act may promote director altruism by reducing the marginal personal sacrifice a director must make to indulge in altruistic behavior).

92 Mae Kuykendall, Symmetry and Dissonance in Corporate Law: Perfecting the Exoneration of Directors, Corrupting Indemnification and Straining the Framework of Corporate Law, 1998 COLUM. BUS. L. REV. 443, 469-70 (1998) (finding that exculpation statutes "create a dissonance between substantive corporate law ... and the remedial substructure").

93 See infra text accompanying notes 94-96.

94 Elson \& Thompson, supra note 9, at 581 (identifying the markets, contracts and other private ordering, the law, and norms as other constraints on director behavior); Fairfax, supra, note 13, at 42829, 432 (recognizing that the threat of harm to a directors' reputation should ensure they fulfill their fiduciary duties but concluding that this threat is not sufficient to ensure appropriate behavior in practice).

95 But see infra Part IV.B (discussing the general ineffectiveness of shareholder voting as a check on directorial power). 
incentive to increase stock price and shareholder wealth. ${ }^{96}$ Second, directors are compensated for their service, oftentimes at least partially in the stock of the corporation. Both the fact of compensation and the particular form of stock payment provide incentive for directors to continue in their current board positions and to perform admirably to attract the prospect of other memberships.

There are also significant reputational constraints on board members. ${ }^{97}$ Service on a major corporate board is an exclusive club, one that many in corporate America would like to join, and one in which current members would like to remain. Reputational constraints are often cited as a theoretical ideal of a mechanism to regulate directorial behavior. ${ }^{98}$ However, reality does not often live up to this ideal for a variety of reasons. In promoting her conception of director altruism, Professor Stout recognized that the private nature of a director's work makes it difficult to produce a public reckoning for misbehavior. ${ }^{99}$ In addition, Professor Lisa Fairfax conducted a review of the wrongdoings at Enron and concluded that "neither the market nor the threat of reputational damages fulfilled their regulatory function for Enron ...." ${ }^{\prime 100}$ Fairfax concluded that the threat of legal sanction may be a necessary signal. $^{101}$ Legal sanction identifies the acts that the law wishes to prevent, and

${ }^{96}$ Fairfax, supra note 13, at 429-30 (stating that when directors "fail to behave responsibly, thereby engaging in conduct that harms shareholders and their profits, the harm is reflected in lowered stock prices;" however, "the capital market effectively regulates corporate conduct by deterring directors from taking actions (or failing to take actions) that adversely affect their corporations' stock price").

${ }^{97} \mathrm{Id}$. at 429 ("As members of these various communities, directors have strong incentives to perform their duties in a manner that does not damage their reputation within these communities.").

98 Id. at 428 (stating that many scholars insist that the desire of directors "to maintain a positive reputation encourages them to perform their fiduciary responsibilities with the appropriate level of diligence" such that legal sanctions are unnecessary); see also Stout, supra note 91, at 682 (stating that the idea of "social sanctions," including loss of reputation, "has attracted much attention from corporate scholars in recent years"). Directors are concerned with their specific reputation on the board as well as their general reputation in the larger community. Fairfax, supra note 13, at 429.

${ }^{99}$ Stout, supra note 91, at 682 (stating that "most of the time, the fear of social sanctions provides only a weak motive for exercising care").

100 Fairfax, supra note 13 , at 430.

${ }^{101}$ Id. at 442-43 ("If there are sufficient signals for directors to use to distinguish between improper and proper conduct and if there is some degree of certainty that improper conduct will lead to legal sanctions, then legal sanctions can serve as powerful constrains on directors.”). 
2007] What's the Cost of A Free Pass? A CALl For the Re-Assessment OF 117 STATUTES THAT ALLOW FOR THE ELIMINATION OF PERSONAL LIABILITY FOR DIRECTORS

identification may be necessary to produce the reputational disincentives that would make the legal constraints effective. ${ }^{102}$

Another argument in favor of a statute allowing the removal of personal liability is that the statute accomplishes nothing new or remarkable. Specifically, corporations have previously limited or eliminated this type of liability through other means; therefore, a provision providing for one additional method of accomplishing this goal should not be a concern. The two primary means by which corporations addressed the personal liability of directors before section 102(b)(7) were by providing indemnification and purchasing insurance. ${ }^{103}$ Buying an insurance policy and providing indemnification both have the same practical effect as eliminating liability under the statute; they provide an alternative source of funds so that the director will not have to personally pay any judgments in satisfaction of a breach of duty claim. If a corporation can indemnify or insure its board members without noticeable negative effects, ${ }^{104}$ why can it not use the charter option as well?

There are meaningful differences between exculpation and indemnification and insurance. First, an indemnification statute has a protective provision built into it forbidding indemnification in derivative actions. ${ }^{105}$ Thus, the indemnification statute expressly prohibits directors from receiving protection if the harm is caused to the corporation itself. ${ }^{106}$ Second, insurance companies provide a meaningful,

${ }^{102}$ Id. at 443 ("The lesson of Enron may not be simply that legal sanctions are necessary to fill the gap when other measures fail, but rather that these other measures may inevitably fail without the presence of legal sanctions.").

103 Bradley \& Schipani, supra note 53, at 32 (stating that "all states permit corporations to indemnify directors for litigation costs directly associated with serving the corporation" and noting that "[c]losely related to the corporation's right to indemnify its directors and officers is its right to procure directors' and officers' (D\&O) liability insurance"); see also Balotti \& Gentile, supra note 11, at 18 ("An amendment under section 102(b)(7) should supplement the protections of directors afforded by director liability insurance and would complement various indemnification rights available to directors.").

104 Balotti \& Gentile, supra note 11, at 18 (noting that "many corporations limit] directors' liability for monetary damages through insurance[,]" and there is no evidence "that this protection has encouraged directors to neglect their duties").

${ }^{105}$ E.g., DEL. CODE ANN. tit. 8, \ 145(a)-(b) (2007); Bradley \& Schipani, supra note 53, at 32. Delaware's statue also a prohibition against indemnification for unlawful or bad faith acts; however, a similar protective provision is found in section 102(b)(7), so that is not a point of difference. DEL. Code ANN. tit. 8, \145(a); Del. CODE ANN. tit. 8, \ 102(b)(7)(ii) (2007).

106 DEL. CODE ANN. tit. 8, $\int 145$ (a)-(b) (prohibiting indemnification in "an action by or in the right of the corporation" and providing that "no indemnification shall be made in respect of any claim, issue 
third-party check on exculpation. By defining the scope of coverage, setting the financial limits of the policy, and determining the premium, the counterparty to the insurance contract has the ability to set forth its conception of good governance and incentivize board members to live up to this conception. No such opportunity exists with section 102(b)(7). Also, a study reported in 1989 by Michael Bradley and Cindy Schipani supports the contention that the mere availability of the exculpation statute did harm shareholders of Delaware corporations. ${ }^{107}$ The authors found a significant decrease in the values of Delaware firms after enactment of section 102(b)(7), indicating that Delaware corporations were hurt by the lesser exposure of directors to personal liability. ${ }^{108}$ The decrease in value indicated that the market viewed potential personal liability as an effective constraint on directors, ${ }^{109}$ and, more generally, that liability rules are important tools in promoting efficient corporate governance. ${ }^{110}$

\section{The Incentive to Shirk Provided by Rule $10 \mathrm{~b}-5$}

The scholarship cited above raises serious doubts about the effectiveness of a regime that does not allow for the imposition of personal liability on directors. However, even if market and reputational checks are adequate to constrain the obvious negative incentive provided by the statute, the more subtle reinforcement of these negative impulses remains. Namely, Rule 10b-5 promulgated under the Securities Exchange Act of $1934^{111}$ and its' scienter requirement remain. ${ }^{112}$ Requiring

or matter as to which such person shall have been adjudged to be liable to the corporation . ..'); Bradley \& Schipani, supra note 52, at 32.

107 Bradley \& Schipani, supra note 52, at 69 (finding that "the market reacts negatively to the announcement that a firm's management has elected to be covered by the provisions of the Delaware statute").

$108 \mathrm{Id}$. at 61 (finding that " $\mathrm{t}]$ he significant decrease in the relative values of Delaware firms in the wake of section 102(b)(7) indicates that the relaxed liability exposure for violations of the duty of care standard allowed by this act is detrimental to the wealth of the stockholders of Delaware firms").

109 Id. at 65 (suggesting "that potential liability for violations of the duty of care standard was an effective constraint on the managers of these firms and that relaxation of this constraint had a detrimental effect on the stockholders of Delaware firms").

${ }^{110} I d$. at 70 (concluding "that liability rules are important for efficient corporate governance”).

111 Ernst \& Ernst v. Hochfelder, 425 U.S. 185, 195 (1976) ("In 1942, acting pursuant to the power conferred by $\int 10(\mathrm{~b})$, the [Securities and Exchange] Commission promulgated Rule 10b-5 . . .") (emphasis in original). 
2007] What's the Cost of a Fre Pass? A CALl FOR THE Re-ASSESSMENT OF 119 STATUTES THAT ALLOW FOR THE ELIMINATION OF PERSONAL LIABILITY FOR DIRECTORS scienter in private rights of action forces plaintiffs to prove the defendants held a certain state of mind when violating the rule-that they acted in a knowing or reckless manner. ${ }^{113}$ Scienter can be inferred, ${ }^{114}$ but the Private Securities Litigation Reform Act requires that litigants "state with particularity facts giving rise to a strong inference that the defendant acted with the required state of mind." 115 This "strong inference" of fraud "must be more than merely plausible or reasonable-it must be cogent and at least as compelling as any opposing inference of nonfraudulent intent." management and oversight of the corporation they have been elected to lead, the lack of scienter will leave them free from personal liability for any material corporate misstatements or omissions under Rule 10b-5.

The countervailing legal standard prohibiting the shirking of directorial responsibilities is the state law duty of care. ${ }^{117}$ The duty of care mandates that

112 Id. at 193 (holding that action under Rule 10b-5 requires scienter and describing scienter as an "intent to deceive, manipulate, or defraud").

113 ATSI Communications, Inc. v. Shaar Fund, Ltd., 493 F.3d 87, 99 n.3 (2d Cir. 2007) (stating that in private securities fraud actions under Rule 10b-5, "scienter requires a showing of intent to deceive, manipulate, or defraud,' or reckless conduct" (internal citations omitted)); Robert N. Clemens Trust v. Morgan Stanley DW, Inc., 485 F.3d 840, 847 (6th Cir. 2007) (quoting Helwig v. Vencor, Inc., 251 F.3d 540, 548 (6th Cir. 2001) (en banc) (recognizing that the Court in Ernst \& Ernst v. Hochfelder did not address whether reckless behavior is sufficient to prove scienter, but concluding that the Sixth Circuit has "'long premised liability on at least reckless behavior") (internal citations omitted).

114 Tellabs, Inc. v. Makor Issues \& Rights, Ltd., 127 S. Ct. 2499, 2504 (2007) (stating that in determining whether the defendants has scienter, the question "is whether all of the facts alleged, taken collectively, give rise to a strong inference of scienter, not whether any individual allegation, scrutinized in isolation, meets that standard") (emphasis in original).

11515 U.S.C. S 78u-4(b)(2) (2007); Tellabs, Inc., 127 S. Ct. at 2504.

116 Tellabs Inc., 127 S. Ct. at 2404-05.

117 In a more limited but critically important set of circumstances, there is another check on directors' behavior, the availability of a due diligence defense for violations of Section 11 of the Securities Act of 1933. Section 11 holds issuers and a number of individuals (including members of the board of directors) strictly liable for any material misstatements or omissions found in a registration statement. Directors can avoid this liability by demonstrating that they have performed a reasonable investigation, and that the reasonable investigation did and should not have discovered the misstatement or omission. The performance of this type of investigation is commonly known as "due diligence." Liability under this section can be massive, and it would be an effective counter-weight to the concern over scienter. However, Section 11 only applies to corporations who file a registration statement containing a material misstatement or omission, a much narrower set of corporations than 
directors act in a reasonably prudent manner ${ }^{118}$ and specifically requires that they make decisions using "all material information reasonably available to them."119 The imposition of a duty of care offsets the uneven penalty provided under a scienter standard which holds engaged directors liable but allows those who are uninvolved to escape personal liability. ${ }^{120}$ The exculpatory statutes remove this countervailing impulse and further incentivize directors to shirk.

This concern that directors may shirk their duties initially sounds fanciful but is not merely hypothetical. The outside acts of directors of both Enron and WorldCom demonstrate the real-world implications of the exculpation of board members from duty of care breaches. In the litigation surrounding both of these matters, outside directors were sued in private rights of action under Rule 10b-5, ${ }^{121}$ and the corporations had charter provisions that eliminated personal liability for duty of care breaches. ${ }^{122}$ Also, investigations into the events leading up to the collapse of both corporations showed gross inattentiveness and failure of board members to live up to their duty of care. ${ }^{123}$

are exposed to 10b-5 liability. See generally Marc I. Steinberg, Understanding Securities Law, \$7.02 (4th ed., Lexis/Nexis Press 2007).

118 See supra note 11 and accompanying text.

119 Smith v. Van Gorkom, 488 A.2d 858, 872 (Del. 1985) ("The determination of whether a business judgment is an informed one turns on whether the directors have informed themselves "prior to making a business decision, of all material information reasonably available to them.”').

120 For an article recognizing this connection, but using it for a different purpose (attempting to provide content to the good faith standard), see Sale, supra note 72, at 489 (noting that situations involving deliberate indifference are of the type evaluated regularly under the scienter standard in federal securities law).

121 E.g., Newby v. Enron Corp. (In re Enron Corp. Sec., Derivative \& "ERISA" Litigation), No. MDL1446, 2007 WL 2455296, at *19, 22 (S.D. Tex. Aug. 24, 2007); In re WorldCom, Inc. Sec. Litigation, No. 02 Civ. 3288DLC, 2005 WL 638268, at*12 (S.D.N.Y. Mar. 21, 2005).

${ }^{122}$ Enron Oregon Corp., Amended \& Restated Articles of Incorporation, Art. VII $\int$ A, (Annex F to the Proxy Statement/Prospectus included in Amended Registration Statement (Form S-4/A, File No. 333-13791, dated Oct. 10, 1996)), http://www.sec.gov.Archives/edgar/data/1024401/000095012996-002469.txt; WorldCom, Inc., Second Amended \& Restated Articles of Incorporation, Art. Ten (Exhibit 3.4 to Registration Statement (Form S-8, File No. 333-68204, dated Aug. 22, 2001)).

123 Dennis R. Beresford, Nicholas B. Katzenbach, \& C.B. Rogers, Jr., Report of Investigation by the Special Investigation Committee of the Board of Directors of WorldCom, Inc., Mar. 31, 2003, at 264, http://fl1.findlaw.com/news.findlaw.com/hdocs/docs/worldcom/bdspcomm60903rpt.pdf 
2007] What's the Cost of A FreE Pass? A CALl FOR THE RE-AsSESSMENT OF 121 STATUTES THAT ALLOW FOR THE ELIMINATION OF PERSONAL LIABILITY FOR DIRECTORS

Enron directors admitted to signing off on company reports with limited or no knowledge of their contents and approving transactions they did not understand. $^{124}$ These directors were also alerted by Enron's auditors that their accounting practices were high risk, tended to push limits, and were at the edge of acceptable practice. ${ }^{125}$ In addition, the directors waived a conflict of interest and allowed its Chief Financial Officer, Andrew Fastow, to act on behalf of special purpose entities who were doing business with Enron. ${ }^{126}$ However, the board had no systems in place to monitor those matters, and this lapse directly contributed to the financial fraud that occurred. ${ }^{127}$

Similarly, independent investigations showed a lack of attentiveness by the directors at WorldCom. ${ }^{128}$ A Special Committee Report illustrated that the audit committee was so disengaged that it virtually had no chance of identifying anything

(hereinafter Special Committee Report) (finding that the there was a "significant failure of corporate governance" at WorldCom and that the directors "played far too small a role in the life, direction, and culture of the Company"); William C. Powers, Jr., Raymond S. Troubh, \& Herbert S. Winokur, Jr., Report of Investigation by the Special Investigation Committee of the Board of Directors of Enron Corp., Feb. 1, 2002, at 22, http://news.findlaw.com/hdocs/docs/enron/sicreport/ (follow "Entire Report" hyperlink) (hereinafter Powers Report) (finding that the directors failed in their oversight duties); see also Bernard Black, Brian Cheffins, \& Michael Klausner, Outside Director Liability, 58 STAN L. REV. 1055, 1121, 1127 (2006) (citing the investigative reports performed on both Enron and WorldCom as being highly critical of the directors' lack of oversight); Fairfax, supra note 13, at 398 (citing investigative reports of Enron and "other corporations embroiled in financial accounting scandals" that indicate directors "failed to fulfill their fiduciary duties ... [and] reveal[ed] their failure to monitor adequately and remain sufficiently informed about the behavior of others ....").

124 Powers Report, supra note 123, at 22-24 (discussing the lack of oversight by the Enron's Board of Directors and stating that they "can and should be faulted for failing to demand more information, and for failing to probe and understand the information that did come to it").

125 Black, Cheffins, \& Klausner, supra note 123, at 1127 (citing an investigate report of Enron indicating the Audit Committee was informed by the auditors "that the company's accounting practices were 'high risk,' tended to 'push limits,' and were 'at the edge' of acceptable practice”).

126 Powers Report, supra note 123, at 8-9 (stating that the directors allowed Mr. Fastow to participate in the LJM partnerships despite the conflict of interest due to him being a manager and investor of the partnerships and the CFO of Enron).

127 Powers Report, supra note 123, at 9-10.

128 Black, Cheffins, \& Klausner, supra note 123, at 1121 (citing two investigative reports finding the directs were "exceedingly passive and utterly failed to perform their oversight responsibilities"). 
other than the most flagrant or obvious financial frauds, ${ }^{129}$ and it also showed that the directors missed several "red flags" that should have alerted them to wrongdoing. ${ }^{130}$ As a whole, the board approved loans to WorldCom's Chief Executive Officer, Bernard Ebbers, on terms that no financial institution would have accepted and approved multi-billion dollar transactions without understanding their substance. ${ }^{131}$

As part of their defense, WorldCom directors claimed that the securities fraud claims should be dismissed because they lacked scienter. ${ }^{132}$ As evidence of this lack of scienter, the directors pointed to the brief meetings, the extreme deference in oversight to the Chief Executive Officer, and the failure to engage in substantive business matters under their purview. ${ }^{133}$ Each of these defenses could also be used as an allegation of a breach of fiduciary duty under state law. ${ }^{134}$ However, because of the exculpatory provision in its charter, WorldCom directors not only escaped liability for breaching their duty of care, but they also attempted to escape federal securities law liability by relying on the fact that they had breached their state law duties.

129 Special Committee Report, supra note 123, at 278 (stating that the directors "played so limited a role in the oversight of WorldCom that it is unlikely that any but the most flagrant and open financial fraud could have come to their attention").

${ }^{130} \mathrm{Id}$. at 30, 282 (stating that the directors "did not function in a way that made it likely that red flags would come to their attention"). The court references four red flags: "(1) questions raised during an earnings conference call on February 7, 2002; (2) the SEC's March 7, 2002 request for documents; (3) the March 11, 2002 Dow Jones Newswire disclosure of the SEC inquiry; and (4) the internal audit in May 2002." In re WorldCom, Inc. Securities Litigation, 294 F. Supp. 2d 392, 418 (S.D.N.Y. 2003).

131 Black, Cheffins, \& Klausner, supra note 123, at 1122, 1123 (noting that no financial institution would have assumed the risk associated with the loans and guarantees made to Ebbers and that multibillion dollar transactions were approved "on the basis of virtually no data").

132 See, e.g., In re WorldCom, Inc. Securities Litigation, 294 F. Supp. 2d at 417 ("The five Director Defendants who have been named in a Section 10(b) claim argue principally that the Section 10(b) claim must be dismissed because there are insufficient allegations of their individual scienter.”).

133 See In re WorldCom, Inc. Securities Litigation, 294 F. Supp. 2d at 418-20; Answer of Director Defendants, 2003 WL 23951686.

${ }^{134}$ For a discussion of the requirements of the duty of care, see generally Franklin A. Gewurtz, Corporation Law, $\int 4.01$ (West Group 2000). 
2007] What's the Cost of A Free Pass? A CALl For the Re-Assessment OF 123 STATUTES THAT ALLOW FOR THE ELIMINATION OF PERSONAL LIABILITY FOR DIRECTORS

\section{B. Section 102(b)(7) Is Not Needed to Satisfy Its Original Purpose}

The second problem created or exacerbated by the exculpatory statute is that it either does not remedy the problems it was designed to fix or those problems did not turn out to be actual causes for alarm. This section closely examines three related issues raised by the case of Smith $v$. Van Gorkom and argues that each provides evidence that the incentives leading to the enactment of section 102(b)(7) were not substantial enough to warrant the particularly drastic response.

\section{The Virtues of Van Gorkom and Corporate Managers as a Special Interest}

Several commentators argued that Smith v. Van Gorkom provided valuable guidance regarding how to conduct oneself as a director consistent with his fiduciary duties rather than signal a cause for alarm for corporate directors. ${ }^{135}$ These commentators look to the enactment of section 102(b)(7), not as a needed remedy to judicial overreaching, but as an opportunistic move by management looking to provide themselves even more favorable circumstances, regardless of the underlying substance of the matter. ${ }^{136}$

In general, these commentators believe that Van Gorkom was simply an application of current Delaware law to the proposed Trans Union transaction and was only novel to the extent that it applied to the facts of the case. ${ }^{137}$ One

135 Daniel, supra note 57, at 633, 644 (concluding that decisions such as Smith v. Van Gorkom "clarify and explain the current standards of conduct for directors"); Mones, supra note 55, at 567 ("The Trans Union decision did not break new ground or introduce radical theories. Rather it followed the basic standards for the application of the business judgment rule established in Aronson v. Lewis . . . ."); Schwartz \& Wiles, supra note 57, at 430 (disagreeing with the suggestion that Smith v. Van Gorkom represents "new law" and finding instead that it "plainly follows long-existing principles of, and cases concerning, corporate governance"); Wagner, supra note 55, at 124 ("[T] he Trans Union Case remains a coherent explication of a long-existing, fundamental safeguard for corporate management. It is neither a departure from previous Business Judgment Rule holdings nor a harbinger of judicial activism in the corporate sphere.").

136 Honabach, supra note 11, at 312 (stating that "section 102(b)(7) proved popular with corporate management" and that this was not surprising); Griffith, supra note 52, at 63 (claiming that "[w]ith the adoption of $\int 102(b)(7) \ldots$ the management lobby won an amendment effectively overturning the decision" of Smith v. Van Gorkom); Lee, supra note 31, at 244 (arguing that "the Delaware-type legislation is an inappropriate response . . that may have deleterious effects on corporate governance").

137 Quillen, supra note 56, at 466 (stating that Smith v. Van Gorkom has "little lasting legal significance" and is "primarily a fact case"); Wander \& LeCoque, supra note 56, at 39 ("[ $\mathrm{n}$ n light of the court's portrayal of the facts, the decision appears to be correct and its outcome note surprising."). 
commentator even identified two beneficial results from $V$ an Gorkom-the increased use of experts by corporate boards and an improved deliberative process for important decision-making. ${ }^{138}$

Most commentators argue that corporate managers exhibited traditional interest group behavior by turning to a favorable venue, the Delaware legislature, for relief when confronted with what they considered an expansion of their recognized sphere of liability. ${ }^{139}$ The Delaware legislature provided that relief at the expense of shareholders. ${ }^{140}$ To the extent this picture is accurate, ${ }^{141}$ using the Delaware legislature in this manner would exemplify the "race to the bottom" theory of state corporate law. ${ }^{142}$ This theory suggests that each state competes for incorporations by pandering to corporate managers and the state that provides the most incentives for managers to desire incorporation in its jurisdiction will be rewarded with a greater proportion of incorporations and their corresponding revenue. ${ }^{143}$ To the extent that

138 Elson \& Thompson, supra note 9, at 584 (tracing two specific alterations in corporate practice to Smith v. Van Gorkom: "1) the widespread use of third party advisers to give expert opinions to the board for various corporate transactions, and 2) the rise of elaborate decision-making procedures ... $. ’)$.

139 Griffith, supra note 52, at 63 (noting that management was able to successfully lobby the legislature to enact section 102(b)(7)); Honabach, supra note 11 (espousing the theory that "the passage of the exculpatory provisions [was] nothing more than another instance in which corporate managers . . . were able to call successfully on state legislators to gain further insulation from shareholder control').

140 Steven A. Ramirez, The Chaos of Smith, 45 WASHBURN L. J. 343, 343 (2006) (claiming that "[s]pecial interest influence took grip of corporate governance in America in the wake of Smith and drastically altered shareholder rights in a most pernicious fashion by eviscerating the duty of care through insulating legislation"); Jeffrey P. Weiss, The Effect of Director Liability Statutes on Corporate Law and Policy, 14 J. Corp. L. 637, 659 (1989) (concluding that "legislatures have gone too far" by granting too many benefits "to corporate management at the expense of shareholder rights" resulting in management no longer being accountable to shareholders).

141 There are those who believe that this jurisdictional competition is good rather than harmful for both shareholders and society. See, e.g., Roberta Romano, Corporate Governance in the Aftermath of the Insurance Crisis, 39 EMORY L. J. 1155, 1156 (1990) (concluding that limited liability statutes are likely to benefit shareholders "by eliminating a class of lawsuits where insurance payouts defray legal costs rather than compensate shareholders").

142 See Weiss, supra note 140, at 638-639 (noting that under the "race to the bottom" theory, revenues are enhanced at the expense of shareholder rights).

143 Weiss, supra note 140, at 639 (arguing "that Delaware . . has enjoyed success in the business of incorporations because of its 'enabling' corporate code and the desire of its judiciary to promote the interests of corporate management at the expense of shareholder protection"). 
2007] What's the Cost of A Free Pass? A CALl For the Re-Assessment OF 125 STATUTES THAT ALLOW FOR THE ELIMINATION OF PERSONAL LIABILITY FOR DIRECTORS the enactment of section 102(b)(7) was a product of a race to the bottom, its validity and usefulness would be called into question.

\section{Was the Insurance Market in Crisis?}

Another question raised regarding the initial enactment of section 102(b)(7) relates to its role as a response to the perceived directors' and officers' insurance crisis. As mentioned, there were three distinct but related problems in the directors' and officers' insurance market after Van Gorkom: (1) premiums were being increased, (2) the scope of coverage was being narrowed, and (3) some corporations were unable to secure coverage at any price. ${ }^{144}$ The questions remain: why were these things happening and was a legislative response necessary or appropriate?

The dominant thesis on this point is that Van Gorkom itself caused the crisis because of the dramatic shift it signaled in the law of fiduciary duties for directors. ${ }^{145}$ This section provides an alternative explanation; the insurance industry took advantage of the uncertainty surrounding the $V$ an Gorkom decision to retain above average premiums for itself. The Bradley and Schipani study supports this decision; it found that, although premiums increased in an unprecedented manner, the market value of insurance carriers increased as well. ${ }^{146}$ Bradley and Schipani interpret this confluence as proof that the premium increases were greater than necessary to offset the added risk created by Van Gorkom. ${ }^{147}$ Thus, although Van Gorkom created some uncertainty and additional risk of liability for directors, the increase in premiums cannot be fully explained as a response to that uncertainty and risk. In fact, the evidence does not show a statistically significant decrease in the value of Delaware corporations after the Van Gorkom decision, a finding that would indicate perceived

144 Lee, supra note 31, at 252-253 (stating that corporations were "unable to obtain D\&O insurance coverage . . . either because premium hikes took on astronomical proportions or because policies simply were not available"); see sources cited supra notes 61-63.

145 Honabach, supra note 11, at 324 (discussing the insurance crisis and stating that " $\mathrm{t}$ ] he causes for the increased rates were multifold, but it became a popular, yet misguided, sport to point to the $V$ an Gorkom decision as a major contributing cause").

146 Bradley \& Schipani, supra note 52, at 48 (finding that Smith v. Van Gorkom decision "was followed by an unprecedented increase in D\&O liability insurance premiums" while "the market value of D\&O liability insurers actually increased in the wake of the decision").

147 Id. (interpreting the rise in insurance premiums and market value of D\&O liability insurers "as evidence that the publicity and hyperbole surrounding Trans Union allowed D\&O liability insurers to increase their premiums beyond the increase in liability exposure created by the decision"). 
harm to shareholders as a result of the holding. ${ }^{148}$ Instead, the decrease in value coincides with the passage of section 102(b)(7), indicating that the most harmful event in this sequence was the removal of the liability sanction for director misconduct. ${ }^{149}$

\section{Resolving the Uncertainty Created by Smith v. Van Gorkom}

Even if the desire for increased revenues by the insurance industry can partially explain the perceived insurance crisis, at least part of the uncertainty and premium increases ought to be fairly laid at the feet of the Van Gorkom decision itself. There was widespread belief before the decision that it was nearly impossible to incur personal liability without a conflict of interest. ${ }^{150}$ Because that impossibility became a reality, a range of unanswered questions confronted onlookers. The only certainty was that the predictability of Delaware law had taken a significant hit. ${ }^{151}$ This section both recognizes those initial questions and argues that the evolution of Delaware common law has answered many of the questions raised by $V$ an Gorkom in a manner that does not raise serious concerns about instability or additional director liability. The incremental approach adopted by Delaware courts in the wake of $V$ an Gorkom is another reason why allowing for the elimination of personal liability by statute seems excessive today.

Van Gorkom replaced predictability with a series of important questions regarding the future of Delaware corporate law. ${ }^{152}$ Immediately after the decision, Professors Burgman \& Cox contemplated the impact $V$ an Gorkom would have on:

the extent to which directors may rely on information and reports generated by insiders; the extent to which it is necessary or advisable

${ }^{148} I d$. (finding that Smith $v$. Van Gorkom "had little to no effect on the value of firms incorporated in Delaware[,]" but the "enactment of section 102(b)(7) is associated with a significant decrease in the equity values of Delaware firms”).

${ }^{149} \mathrm{Id}$. (stating that "after the enactment of section 102(b)(7), premiums began to fall and the growth in the market value of the equities of these insurers subsided").

150 See supra notes 31-33 and accompanying text.

${ }^{151}$ Herzel \& Katz, supra note 50, at 1190 (opining that "[o]ne important effect of Smith v. Van Gorkom is likely to be much greater randomness and unpredictability on the part of future courts passing on future board decisions").

${ }^{152} I d$. 
2007] What's the Cost of A Free Pass? A CALl For the Re-AsSESSMENT OF 127 STATUTES THAT ALLOW FOR THE ELIMINATION OF PERSONAL LIABILITY FOR DIRECTORS

to seek the advice of investment bankers or other outside experts; the extent to which reliance on the advice of counsel will provide business judgment protection; and the effect of shareholder ratification on the directors' actions. ${ }^{153}$

Even three years after Van Gorkom, Professors Macey and Miller struggled with the long-term implications of the decision. ${ }^{154}$

At every turn, subsequent Delaware court decisions minimized the concerns initially raised with $\operatorname{Van}$ Gorkom. Almost immediately following Van Gorkom, the decision in Rosenblatt v. Getty Oil Co. ${ }^{155}$ indicated that Delaware courts were not making as striking a departure from precedent or prior judicial philosophy as some had feared. ${ }^{156}$ Shortly thereafter, the Hanson $I I^{157}$ opinion reinforced the view that $V$ an Gorkom was strictly a process decision and not an invitation for courts to gut the business judgment rule and regularly scrutinize the substance of board actions. ${ }^{158} \mathrm{~A}$ full decade after $V$ an Gorkom, one of the many opinions to arise from the Technicolor litigation ${ }^{159}$ lent even further support to the proposition that $V$ an

153 Burgman \& Cox, supra note 47, at 313.

154 Jonathan R. Macey \& Geoffrey P. Miller, Trans Union Reconsidered, 98 YALE L. J. 127, 129 (1988) (identifying the following problems when Smith $v$. Van Gorkom is viewed as a business judgment case: (1) "the court defined the applicable standard of care as gross negligence, [yet] seemed to apply a more stringent standard on the facts of the case;" (2) the decision "appears to depart dramatically from prior law and to upset settled expectations;" (3) the case "displays a mysterious anti-management bias;" and (4) "the remedy prescribed by [the case] appears to be largely cosmetic and even selfdefeating").

155 Rosenblatt v. Getty Oil Co., 493 A.2d 929 (Del. 1985).

156 Quillen, supra note 56, at 481, 488 (stating that "[i]n one respect, Rosenblatt completely obliterates Trans Union and takes a giant step into principled decision making" and concluding that Rosenblatt serves “as an excellent brake to fears of a Trans Union erosion”).

${ }^{157}$ Hanson Trust PLC v. SCM Corp. (Hanson II), 774 F.2d 47 (2d Cir. 1985).

158 Wander \& LeCoque, supra note 56, at 41 (claiming that "[b]oth Van Gorkom and Hanson II underscore the critical need for careful preparation and documentation in connection with the handling of takeover and merger proposals").

${ }^{159}$ Cinerama, Inc. v. Technicolor, Inc. (Technicolor III), 663 A.2d 1156 (Del. 1995). 
Gorkom was an application of uncontroversial and straightforward principles of Delaware law to an unusual and unique set of facts. ${ }^{160}$

Subsequent events have also diminished fears regarding the other impacts of $V$ an Gorkom. The anticipated wave of decisions imposing liability on boards never occurred. A detailed study by Professors Black, Cheffins, and Klausner found only thirteen instances in which outside directors made personal payments to resolve litigation since 1980, including Van Gorkom itself. ${ }^{161}$ Van Gorkom was the only case identified in the sample in which directors made a personal payment after a trial, the other twelve involved pre-trial settlements. ${ }^{162}$ Van Gorkom is also the only case of oversight failure in which the company remained solvent. ${ }^{163}$ These findings underscore the rarity of imposing personal liability on directors, and, even within these rare cases, the unusual posture of $V$ an Gorkom. ${ }^{164}$ Part of this absence of director liability may be attributable to the exculpatory statute itself. ${ }^{165}$ However, the statute did not become effective until July $1,1986,{ }^{166}$ and there is no case imposing

${ }^{160}$ Bryan C. Bacon, Note, Redefining Director Liability in Duty of Care Cases: The Delaware Supreme Court Narrows Van Gorkom, 61 Mo. L. REV. 663, 675 (1996). Bacon noted the "great deal of controversy" over what impact Smith v. Van Gorkom would have on corporate law. Id. The majority of commentators suggested that the case "would have broad and disastrous effects upon corporate law." Id. "However, a significant minority of commentators asserted that Van Gorkom did not mark a departure from existing law and its application would essentially be limited to its facts." Id. Bacon concludes that the "a careful reading of Technicolor III suggests that the latter view has prevailed." Id.

${ }^{161}$ Black, Cheffins, \& Klausner, supra note 123, at 1059-60 (finding that "out-of-pocket payments by outside directors are rare" and noting only twelve cases where payments were made before trial for settlement and associated legal expenses and only one case, Smith v. Van Gorkom, where payment was made by directors after trial).

${ }^{162} I d$.

$163 \mathrm{Id}$. at 1074 (finding that "[a]mong the cases of oversight failure, only Van Gorkom involved a solvent company, ... [and that] insolvency is essentially a prerequisite to outside director liability for oversight failure").

${ }^{164}$ Id. at 1094 (noting that " $[\mathrm{w}]$ here failure is one of oversight as opposed to one of loyalty, a plaintiff alleging a breach of duty under corporate law is highly unlikely to win the case on the merits against an outside director").

$165 \mathrm{Id}$. at 1090-91 (concluding that in the face of a exculpatory provision under section 102(b)(7) or similar statute, "[e]stablishing even nominal liability against an outside director for a duty of care breach is exceedingly difficult").

166 Hanks, supra note 71, at 1210; Honabach, supra note 11, at 323 ("There are no reported cases imposing liability on directors for acts that occurred prior to the effective date of any of those statutes.”). 
2007] What's the Cost of A Free Pass? A CALl For the Re-Assessment OF 129 STATUTES THAT ALLOW FOR THE ELIMINATION OF PERSONAL LIABILITY FOR DIRECTORS such liability between Van Gorkom and the statute's effective date. These facts coupled with the case law described above point to the conclusion that the sea change in Delaware law feared after Van Gorkom never came to fruition. ${ }^{167}$

\section{Courts Are Replacing Due Care with Good Faith}

Another problem with the current situation involving exculpatory statutes is that courts do not want to respect the shareholders' decision to eliminate liability. In the wake of the bursting of the dot-com bubble, a number of corporate scandals have occurred at places such as Enron, WorldCom, Tyco, Global Crossing, Adelphia Communications, and many others. ${ }^{168}$ When confronted with these recent breaches of the duty of care, courts have not simply dismissed cases. Instead, Delaware courts introduced a new prominence of the duty of good faith to confront the same problems that were traditionally handled by the duty of care. ${ }^{169}$ This trend ignores the purported will of shareholders and causes uncertainty in Delaware law. Because these claims are factually similar to prior duty of care cases, courts are ignoring the will of shareholders and relying solely on the duty of good faith when companies have exculpatory provisions in their charters that waive personal liability for duty of care breaches. This trend causes uncertainty in two ways. First, the substance of the

167 In an interesting study, Helen Bowers also demonstrates that a less worrisome, but very commonly predicted, negative reaction to Van Gorkom never came to pass-the expectation that every board was going to feel the need to secure a fairness opinion after the decision. Helen M. Bowers, Fairness Opinions and the Business Judgment Rule: An Empirical Investigation of Target Firms' Use of Fairness Opinions, 96 Nw. U. L REV. 567, 568, 577 (2002) (casting doubt on the widely held perceptions that it is now uniform practice for target firms to obtain fairness opinions). Her empirical results demonstrate an insignificant increase in the percentage of fairness opinions secured before and after Van Gorkom. Id.

168 Corporate Scandal Primer, washingtonpost.com, http://www.washingtonpost.com/wpsrv/business/scandals/primer/index.html (last visited Nov. 16, 2007); Penelope Patsuris, The Corporate Scandal Sheet, Forbes.com, Aug. 26, 2007, http://www.forbes.com/2002/07/25/accountingtracker.html.

169 See Fairfax, supra note 13, at 417 (stating that "by essentially recharacterizing duty of care claims as breaches of the duty of good faith, Delaware courts may have discovered a way to impose financial liability on directors who breach their fiduciary duty of attention and inquiry"); Jaclyn J. Janssen, Note, In re Walt Disney Company Derivative Litigation: Why Stockholders Should Not Put Too Much Faith in the Duty of Good Faith to Enhance Director Accountability, 2004 WiSC. L. REV. 1573, 1599-1600 (2004) (stating that "[i]f Delaware courts were going to get tough on fiduciary duty law, the duty of good faith was the courts' only option"); Thomas Rivers, Note, How to be Good: The Emphasis on Corporate Directors' Good Faith in the Post-Enron Era, 58 VAND. L. REV. 631, 654 (2005) (stating that "[i]n the wake of Enron and other corporate governance scandals, courts have resuscitated Van Gorkom-style procedural review by framing the issue as one of good faith"). 
duty of good faith is unsettled. Second, the scope of the effectiveness of the waiver of liability for a breach of the duty of care is uncertain because of the indeterminate overlap between the duty of care and the duty of good faith.

This section evaluates the phenomenon of replacing due care claims with good faith claims, investigates the lack of use or definition of the concept of good faith, and reviews some attempts by courts and theorists to construct a workable definition. This section concludes that courts and shareholders would be better served by a clear distinction between due care and good faith claims and the questionable enforceability of the protections of section 102(b)(7) is another element against the status quo.

\section{The New Prominence of Good Faith}

The Van Gorkom decision was rendered during a time of turmoil in the corporate world. Hostile takeovers had recently presented a challenge to incumbent boards, and both corporations and the judiciary were dealing with issues that raised novel questions of law. Those societal forces provided a backdrop for the $V$ an Gorkom case, and commentators suggested that the possibly novel imposition of liability for breach of the duty of care was a judicial reaction to these pressures. ${ }^{170}$

Similar changes have occurred in the world of corporate law over the last few years. Corporate failures and scandals have remained in the media, resulting in the passage of the Sarbanes-Oxley Act of $2002^{171}$ and sweeping new governance rules at the New York Stock Exchange. ${ }^{172}$ The market for directors' and officers' liability insurance is once again in turmoil. ${ }^{173}$ In the private sector, numerous investor suits have been filed as increasingly active institutional investors seek to hold directors liable. $^{174}$ However, unlike in 1985 , almost all major corporations have a provision in

\footnotetext{
170 See Robert W. Hamilton, The State of State Corporation Law: 1986, 11 Del. J. Corp. L. 3, 7 (1986).

171 Sarbanes-Oxley Act of 2002, Pub. L. No. 107-204, 116 Stat. 745.

172 See Elizabeth Bumiller, Bush Signs Bill Aimed at Frand in Corporations, N.Y. TIMES, July 31, 2002, at A1; New York Stock Exchange Listed Company Manual, \303A (Nov. 4, 2003), http://www.nyse.com/pdfs/finalcorpgovrules.pdf.
}

\footnotetext{
${ }^{173}$ Fairfax, supra note 13, at 415 (stating that a similar increase insurance premiums and difficulty in obtaining directors' and officers' insurance that occurred following Smith v. Van Gorkom, has occurred "in the wake of the passage of Sarbanes-Oxley and litigation surrounding corporate governance scandals").

${ }^{174}$ Dunn, supra note 22, at 540 (claiming that "the increased litigation activity of institutional investors and their interest in forcing directors to pay out-of-pocket for corporate failures has created a
} 
2007] What's the Cost of A FreE Pass? A CALl FOR THE RE-AsSESSMENT OF 131 STATUTES THAT ALLOW FOR THE ELIMINATION OF PERSONAL LIABILITY FOR DIRECTORS

their charter eliminating personal liability of directors to the fullest extent permitted by law. ${ }^{175}$ Therefore, plaintiffs are re-characterizing the same factual allegations traditionally portrayed as a breach of the duty of care as a breach of the duty of good faith instead. ${ }^{176}$ A good faith claim may succeed where a due care claim fails because section 102(b)(7) specifically prohibits the elimination of personal liability for actions not taken in good faith. ${ }^{177}$ This re-characterization is finding some success in courts across the country. ${ }^{178}$ This confluence of factors has led to a greater examination of the duty of good faith. ${ }^{179}$

Many commentators have noted the recent prominence of the duty of good faith in Delaware jurisprudence. ${ }^{180}$ Hillary Sale argued that the use of good faith is a

corporate governance climate that increases the likelihood that corporate directors could be personally liable in certain circumstances").

175 See supra note 26 and accompanying text; see also Fairfax, supra note 13, at 416 (finding "evidence that Sarbanes-Oxley may play a role in increasing director liability by altering the manner in which state courts view exculpatory statutes").

176 See supra note 170.

177 DEL. CODE ANN. tit. 8, \102(b)(7)(ii) (2007) (providing that a provision eliminating or limiting the personal liability of a director "shall not eliminate or limit the liability of a director: . . (ii) for acts or omissions not in good faith or which involve intentional misconduct or a knowing violation of law").

178 Robert Baker, In Re Walt Disney: What it Means to the Definition of Good Faith, Exculpatory Clauses, and the Nature of Executive Compensation, 4 FLA. ST. U. BUS. REV. 261, 270 (noting that in the aftermath of the Enron and WorldCom scandals, "several decisions in different jurisdictions throughout the country, interpreting corporate law similar to Delaware's, [have] conclude[ed] that corporate board actions were not done in good faith").

179 Dunn, supra note 22, at 562 (asserting that "a considerable amount of the substantive exploration of good faith has played out against the backdrop of the current corporate climate and the increased focus on director conduct").

${ }^{180}$ David H. Cook, The Emergence of Delaware's Good Faith Fiduciary Duty: In re Emerging Communications, Inc. Shareholders Litigation, 43 DUQ. L. REV. 91, 94 (2004) (asserting that "the enactment of Section 102(b)(7) also unwittingly turned the notion of good faith into a protean concept"); C.G. Hintmann, Comment, You Gotta Have Faith: Good Faith in the Context of Directorial Fiduciary Duties and the Future Impact on Corporate Culture, 49 ST. LOUIS U. L. J. 571, 572 (2005) (noting the "marked shift within courts during the last few years to focus on the good faith of corporate directors" as "Delaware and other states have recently enacted new provisions that have thrust the duty of good faith into the limelight as the central focus in a court's fiduciary duty inquiry"); Janssen, supra note 169, at 1574 (stating that "[n]umerous academics and practitioners predict that the duty of good faith is poised to become stockholders' most popular weapon for establishing director liability"). 
promising development in the drive toward more accountable corporate governance. ${ }^{181}$ Others are not as sanguine on the prospects of good faith making a positive impact on corporations or the law. ${ }^{182}$ Sean Griffith puts forward an intriguing theory on the recent use of good faith by arguing that Delaware courts use good faith as a rhetorical device, in a manner similar to due care in Van Gorkom, to designate conduct as culpable, even when the substantive standards do not impose liability. ${ }^{183}$ In recent good faith jurisprudence, Griffith identified some elements of duty of care cases and other elements of duty of loyalty cases, but no situation where either a duty of care or loyalty case was fully proven on its own. ${ }^{184}$ Griffith further argued that courts blend these two causes of action to assign blame in a situation where traditional doctrinal elements are missing for the implied purpose of increasing accountability at the expense of board authority. ${ }^{185}$

\section{Good Faith-The Amorphous Concept and the Search for Definition}

Although good faith has been relied upon more heavily in recent years, there is little information about what elements constitute the duty of good faith. ${ }^{186}$ Shortly after the enactment of section 102(b)(7), commentators began to contemplate how

181 Sale, supra note 72, at 462 (claiming that the duty of good faith "holds considerable promise for creating incentives to instill effective corporate governance").

182 E.g., Janssen, supra note 169, at 1575 (concluding that "the duty of good faith is a weak method for increasing director accountability and combating corporate misdeeds").

183 Griffith, supra note 52, at 34 (arguing that "good faith is used as a loose rhetorical device that courts can wield to find liability or enjoin actions that do not quite fit within established doctrinal categories").

${ }^{184} \mathrm{Id}$. at 35 (reviewing different cases and stating that "[n]either traditional standard [of the duty of good faith and care] would have enabled the plaintiffs to prevail, but when spun together, the elemnts of each analysis make the board appear to have done something sufficiently blameworthy to rule in the plaintiffs' favor"). According to Griffith, "the pattern in the good faith cases is to raise issues under both the duty of care and the duty of loyalty, ... [and then] blend the issues together and, in doing so, identify a basis for liability under the duty of good faith." Id. at 6.

185 Id. at 44 (concluding that "by blending the duties of care and loyalty," good faith "moves the frontier on the spectrum of authority and accountability away from board authority and toward judicial accountability”).

$186 I d$. at 4 (finding that the function and operation of good faith in the law are difficult and unclear concepts that are often contextually dependent). 
2007] What's the Cost of a Free Pass? A Call For the Re-Assessment of 133 STATUTES THAT ALLOW FOR THE ELIMINATION OF PERSONAL LIABILITY FOR DIRECTORS

to distinguish a lack of the duty of care from acts not taken in good faith. ${ }^{187}$ In an early commentary on the statute, Professor Melvin Eisenberg noted that the meaning of good faith had not been judicially interpreted. ${ }^{188}$ A good deal of that uncertainty persists today. There are no definitive statutory or judicial definitions. ${ }^{189}$ Often, courts aver to the existence of good faith without providing any content as to its meaning. ${ }^{190}$ In general, courts agree that some decisions are just so unsound, whether substantively or procedurally, that the good faith of the decision-makers is called into question. ${ }^{191}$

The scope of good faith is turning into a critical issue, and several courts and commentators have recently grappled with it, ${ }^{192}$ most prominently in the case of Brehm v. Eisner, ${ }^{193}$ a case that is commonly referred to as Disney. Prior to Disney, courts identified possible breaches of the duty of good faith when a decision was "so far beyond the bounds of reasonable judgment" that it was otherwise inexplicable, ${ }^{194}$

187 Balotti \& Gentile, supra note 11, at 16 (noting that "it is unclear whether section 102(b)(7) would protect a director against liability for reckless acts" because, "to the extent recklessness involves conscious disregard of a known risk, such conduct is not taken in good faith and thus would not be a liability subject to limitation or elimination under section 102(b)(7)"); David S. Schaffer, Jr., Note, Delaware's Limit on Director Liability: How the Market for Incorporation Shapes Corporate Law, 10 HARV. J.L. \& PUB. POL'Y 665, 669 (1987) (recognizing that a court "could hold that all 'grossly negligent' behavior is per se in 'bad faith' and thus a violation of the duty of loyalty").

188 Eisenberg, supra note 14, at 970 (recognizing that the phrase "acts or omissions not in good faith or which involve intentional misconduct" will have to be interpreted by the courts and stating that "a complete failure to monitor, or to follow up on an information that requires further inquiry, might be construed as 'willful misconduct"').

189 Griffith, supra note 52, at 4 (finding that "the principle [of good faith] is defined neither in the Delaware statute nor in judicial precedent”).

${ }^{190}$ Dunn, supra note 22, at 545-46 (discussing the lack of "doctrinal clarity" for good faith and nothing that courts often refer to good faith but have traditionally "not substantively defined the duty of good faith").

191 Rivers, supra note 169, at 656 (arguing that "some decisions . . . are so substantively or procedurally unsound that they could not have been made in good faith").

192 Veasey \& DiGuglielmo, supra note 16, at 1452 (stating that "the real issue is understanding the definition, scope, and operational application of the amorphous concept of good faith").

193 Brehm v. Eisner (In re Walt Disney Co. Derivative Litigation) (Disney), 825 A.2d 275 (Del. Ch. 2003). 
when there was evidence of irrationality, ${ }^{195}$ when directors pledged valuable assets to secure personal loans of its Chief Executive Officer with no corresponding corporate benefit, ${ }^{196}$ or when conduct was simply too "egregious" for the court to tolerate. ${ }^{197}$

Factually, Disney resembled Van Gorkom in several respects. ${ }^{198}$ Both cases claimed harm through a lack of attentiveness by the board to important corporate affairs-Van Gorkom to an acquisition and Disney to a lucrative and allegedly unjust employment contract. ${ }^{199}$ Both cases showed a lack of oversight by the board in performing its responsibilities. ${ }^{200}$

${ }^{194}$ Janssen, supra note 169, at 1583. According to Janssen, "good faith is called into question when 'a decision is so far beyond the bounds of reasonable judgment that it seems essentially inexplicable on any ground other than bad faith." Id. (quoting In re J.P. Stevens \& Co., Inc. Shareholders Litigation, 542 A.2d 770, 780-81 (Del. Ch. 1988)). It is also "suggested that a breach of the duty of good faith require[s] a substantive review.” Id. (citing White v. Panic, 783 A.2d 543, 554 n.36 (Del. 2001)).

195 Rivers, supra note 169, at 636 (citing Parnes v. Bally Entm't Corp., 722 A.2d 1243, 1246-47 (Del. 1999)) (showing "that, in practice as well as in theory, irrationality may support a finding of bad faith without additional evidence of self-dealing or a lack of due care").

196 John L. Reed \& Matt Neiderman, "Good Faith" and the Ability of Directors to Assert $\int 102(b)(7)$ of the Delaware General Corporation Law as a Defense to Claims Alleging Abdication, Lack of Oversight, and Similar Breaches of Fiduciary Duty, 29 DEL. J. CORP. L. 111, 117 (2004) (citing Emerald Partners v. Berlin, No. 9700, 1993 De. Ch. LEXIS 273, at *21-22 (Del. Ch. Dec. 23, 1993)) (claiming "that if the defendantdirectors knowingly approved a transaction in which the corporation received no consideration in return for the pledge of valuable corporate assets to secure the personal loans of its Chief Executive Officer, ... S 102(b)(7) would not protect them from personal liability because they would have acted in bad faith"').

${ }^{197}$ Id. at 122 (citing Citron v. Fairchild Camera \& Instrument Corp., No. 6085, 1988 Del. Ch. LEXIS 67 (Del. Ch. May 19, 1988)) (using Citron's reasoning to conclude that "misconduct otherwise implicating due care could be so egregious as to create an inference of bad faith, even absent an improper financial benefit").

198 Janssen, supra note 169, at 1595 (claiming that, "[i]n many respects, Disney is a replay of Smith v. Van Gorkom").

${ }^{199} I d$. at $1592,1595$.

200 The courts in both Smith v. Van Gorkom and Disney "faulted the board for three main deficiencies:" (1) for spending "a minimal amount of time reviewing material information before granting their approval;" (2) for "rel[ying] on only rough summaries of the transactions and . . not adequately inquir[ing] as to the foundation or implications of the actual agreements;" and (3) for not hiring "an expert to provide advice regarding the merger or employment agreement respectively." Id. at 1595-96. 
2007] What's THE COST OF A FreE PASS? A CALL FOR THE RE-ASSESSMENT OF 135 STATUTES THAT ALLOW FOR THE ELIMINATION OF PERSONAL LIABILITY FOR DIRECTORS

However, one major difference between the two scenarios is that Disney's charter contained an exculpatory clause eliminating personal liability for duty of care breaches. ${ }^{201}$ Because of this critical distinction, the Disney shareholders could not succeed in an action for a breach of the duty of care and were forced to rely on the duty of good faith. ${ }^{202}$ In fact, the original Disney complaint was dismissed because it alleged primarily duty of care claims, and only upon being allowed to re-plead did the shareholders focus on the duty of good faith. ${ }^{203}$ Although the Disney Court did not find wrongdoing by the directors, it did note that a deliberate failure to act in the face of a duty to do so was sufficient evidence to constitute a breach of the duty of good faith. ${ }^{204}$

In one sense, Disney is simply a continuation of the unclear delineation of Delaware's doctrine of good faith. In another sense, the decision harms Delaware law in two ways. First, it is an unprecedented application of the doctrine of good faith, so any observer or corporate official trying to adhere to his good faith

${ }^{201} I d$. at 1596; Walt Disney Co., Restated Certificate of Incorporation of the Walt Disney Company, Art. IX, available http://corporate.disney.go.com/media/corporate/DisneyCertificateofIncorporation.pdf (providing that "[a] director of this Corporation shall not be liable to the Corporation or its stockholders for monetary damages for breach of fiduciary duty as a director, except to the extent such exemption from [sic] liability or limitation thereof is not permitted under the DGCL”).

${ }^{202}$ Baker, supra note 178, at 262 (arguing "that a fair reading of the Disney case essentially aligns the duty of good faith with the traditional duty of care, which would greatly diminish, if not render meaningless, the use of such exculpatory provisions"); Griffith, supra note 52, at 22-23 (finding that the allegations in Disney "would typically form the basis of a complaint under the duty of care, but the court did not pursue the analysis, perhaps because the business judgment rule and 102(b)(7) provision would have kept it from getting very far"); Janssen, supra note 169, at 1596 (stating that because the exculpation clause prevented an action for breach of the duty of care, "the Disney stockholders needed to plead that the directors breached another fiduciary duty" which they did in "a possible good faith breach").

203 Rivers, supra note 169, at 646 (finding that the "amended [Disney] complaint alleg[ed] that the directors should be held personally liable for a knowing or intentional lack of due care in their decision-making process" and the court held that this complaint sufficiently alleged that the " "directors failed to exercise any business judgment and failed to make any good faith attempt to fulfill their fiduciary duties to Disney and its stockholders"'); Veasey \& DiGuglielmo, supra note 16, at 144041 (noting that Disney was initially a due care case that was repleaded and "morphed into a 'good faith' case").

204 Brehm v. Eisner (In re Walt Disney Co. Derivative Litigation), 906 A.2d 27, 61-62 (Del 2006) (affirming the Chancellor's conclusion that plaintiffs "failed to establish any lack of due care on the directors' part;" but stated that "[d]eliberate indifference and inaction in the face of a duty to act is ... conduct that is clearly disloyal to the corporation"). 
obligations must now hit a moving target. ${ }^{205}$ Second, Disney blurred the line between good faith and gross negligence jurisprudence. ${ }^{206}$ It is now difficult to distinguish where a director's negligence under the duty of care ends and where violations of the duty of good faith begin.

At least one commentator has attempted to grapple with this problem. Hillary Sale recognized the need to distinguish between a breach of the duty of good faith and a breach of the duty of care. ${ }^{207}$ However, in attempting to make this distinction, Sale stated that:

Fiduciaries acting in good faith abide by the norms of corporate governance and comply with legal standards while performing their jobs. Egregious or conspicuous failures to do so are subject to liability under the duty of good faith. ... When fiduciaries make material decisions, they need to assure themselves that they know all of the material and reasonably available facts and options before embarking on a major program, granting their approval, or discontinuing an investigation. They cross the line when they abdicate, subvert, or ignore these responsibilities, or act with deliberate indifference toward them. ${ }^{208}$

While these concepts lay out a promising starting point, note the similarity to a traditional statement of gross negligence by a Delaware court: "[i]n the corporate area, gross negligence would appear to mean, 'reckless indifference to or a deliberate disregard of the stockholders,' or actions which are 'without the bounds of reason.",209 While overlap between gross negligence and good faith is possible, the

\footnotetext{
205 Griffith, supra note 52, at 19 (claiming that the "application of good faith [in Disney] was unprecedented in Delaware").
206 Baker, supra note 178, at 269 (suggesting that "the Disney decision blurs the line between [an] elevated recklessness standard for good faith and the traditional gross negligence standard for duty of care breaches").
207 Sale, supra note 72, at 488 (arguing that "[t]o further define the boundary of good faith, [it] must be separate[ed] from what a defendant might prefer to characterize as a care-based situation").
${ }^{208} I d$. at $485-86$.

${ }^{209}$ Reed \& Neiderman, supra note 196, at 126 (quoting Rabkin v. Philip A. Hunt Chemical Corp., 547 A.2d 963, 970 (Del. Ch. 1986)). Similar language is also found in Disney which states that " $[\mathrm{k}]$ nowing or deliberate indifference by a director to his or her duty to act faithfully and with appropriate care is conduct ... that may not have been taken honestly and in good faith to advance the best interests of 
2007] What's the Cost of a Free Pass? A CALl For the Re-Assessment OF 137 STATUTES THAT ALLOW FOR THE ELIMINATION OF PERSONAL LIABILITY FOR DiRECTORS

two concepts should not coincide entirely. General principles of statutory interpretation dictate that different terms within the same section ought to have different meanings. While one could argue that there are fine points of distinction between the two definitions above, there is a long way to go in separating good faith from gross negligence.

\section{CONTRACTARIAN THEORY}

This Article has argued that section 102(b)(7) introduced difficulties into Delaware's corporate law by creating poor incentives for directors, by failing to satisfy its original objectives, and by vaulting the current muddle that is the duty of good faith into prominence. ${ }^{210}$ However, the story of these "charter option" exculpatory statutes is more complex. This Part examines the positive attributes of the statute, explores the real gains and limits of this approach, and finds a useful middle ground for improvement based on the empirical research coming out of the field.

\section{A. Theoretical Support for the Statute}

\section{The Basics of Contractarianism}

A leading model for describing and explaining the corporate form is the contractarian theory of the firm. ${ }^{211}$ This theory states that the corporation should not be viewed as a distinct entity, but rather as a nexus of contracts among the various factors of input. ${ }^{212}$ Shareholders provide capital in return for the residual economic interest in the corporation, limited control rights, and the benefit of fiduciary duties. ${ }^{213}$ Debt holders also provide capital, but on different terms from

the company." Id. at 131 (quoting Brehm v. Eisner (In re Walt Disney Co. Derivative Litigation), 825 A.2d 275, 289 (Del. Ch. 2003)).

210 See supra Part II.

211 See generally Henry N. Butler \& Larry E. Ribstein, Opting Out of Fiduciary Duties: A Response to the Anti-Contractarians, 65 WASH L. REV. 1 (1990) (discussing the contractarian view of the corporation).

${ }^{212} I d$. at 7 (noting that " $[\mathrm{t}]$ he contractual theory of the corporation states that the corporation is a set of contracts among the participants in the business, including shareholders, managers, creditors, employees and others").

213 See Stephen M. Bainbridge, Corporation Law and Economics, 65-68 (Foundation Press 2002). 
shareholders. Instead of a residual economic interest, debt holders receive a defined amount in preference to shareholders. Instead of control rights or fiduciary duties, debt holders receive only the benefit of contract rights. ${ }^{214}$ Capital is not the only factor considered under contractarianism; employees supply labor, and directors and senior executives supply governance and strategic insight.

This model is distinct in that the corporation itself is not considered a separate party to the "contract" with interests distinct from the others. ${ }^{215}$ Rather, under this model, the parties should be able to alter the nature of their relationship however they choose. ${ }^{216}$ One of the primary critiques of contractarianism is that most of the parties do not actually participate in any negotiation; therefore, there can be no meaningful consent. ${ }^{217}$ In other words, the corporate contract is one of adhesion. $^{218}$ Even though most parties do not actually participate, contractarians view the availability of a large number of investment choices as providing options of different sets of contract terms to a prospective investor. ${ }^{219}$ Because of the wide range of choices from one package to the next, contractarians assert that the investor makes a free and informed decision. ${ }^{220}$

${ }^{214}$ Id. at 68-69.

215 See Butler \& Ribstein, supra note 211, at 2-3 (stating that "[c]ontractarians view the corporation as a set of private contractual relationships among providers of capital and services”).

216 Id. at 7-8 (stating that "private parties to the corporate contract should be free to order their affairs in whatever manner they find appropriate").

217 See Victor Brudney, Corporate Governance, Agency Costs, and the Rhetoric of Contract, 85 COLUM. L. REV. 1403, 1420 (1985) (stating that shareholders "have little or no ability to choose or negotiate the terms of management").

$218 I d$. at 1424 (stating that "elements of a contract of adhesion infect the [shareholder's] choice of management if that choice is characterized as 'contractual' by reason of the choice offered to buy or sell stock on the market'); see also Butler \& Ribstein, supra note 211, at 13 (addressing Brudney's argument that the corporate contract is an adhesion contract).

219 Butler \& Ribstein, supra note 211, at 13 ("If contractual volition is lacking-if, as Brudney argues, these are 'adhesion' contracts-it is only in the sense that investors do not dicker over individual terms, but accept contractual packages. This wide range of choices among 'adhesion' contracts means, in effect, that there is no such thing as an adhesion contract.").

220 See source cited supra note 215. 
2007] What's the Cost of A Free Pass? A CALl For the Re-Assessment OF 139 STATUTES THAT ALLOW FOR THE ELIMINATION OF PERSONAL LIABILITY FOR DIRECTORS

One fundamental assertion of contractarians, and one that is contested by more traditional corporate law scholars, is that all terms of the corporate "contract" are subject to negotiation and pricing, including the imposition of fiduciary duties. ${ }^{221}$ This concept is central because traditional scholars view fiduciary duties as being imposed for the benefit of all investors, sophisticated and naïve, current and future, and believe that one group is incapable of waiving those duties for all shareholders. ${ }^{222}$ Contractarians, in contrast, do not see a principled distinction between the ability to waive fiduciary duties and, for example, the ability to demand a preferred dividend. ${ }^{223}$ Each choice has a value to shareholders, and current and prospective parties to the "contract" can assess the value of those provisions along with the rest of the package.

\section{Contractarianism's Claim to Fairness}

In simple terms, the contractarian's response to assertions of fairness is that investors get what they pay for; any dissatisfying terms are offset by a lower price. ${ }^{224}$ Contractarians do not assert that every economic factor, governance nuance, jurisdictional advantage or disadvantage, or any other item impacting value is expressly considered, weighed, and assigned a value by every investor. Rather, contractarians rely on the efficiency of the capital markets to incorporate these price terms for investors. ${ }^{225}$ Under this theory, markets are informationally efficient, rapidly incorporate publicly available information into the market price of securities,

\footnotetext{
221 Butler \& Ribstein, supra note 207, at 28 (stating the "hotly disputed" assertion that "fiduciary duties are a term of the corporate contract and therefore consensual in nature").

222 See, e.g., William W. Bratton, Jr., The "Nexus of Contracts" Corporation: A Critical Appraisal, 74 CORNELL L. REV. 407 (1989).

${ }^{223}$ BAINBRIDGE, supra note 213, at 28.
}

224 Butler \& Ribstein, supra note 211, at 33 (arguing that "a corporate shareholder gets what he is paying for in both the terms of the contract and the substantive nature of the product, including the quality of management").

225 Paul N. Cox, Reflections on Ex Ante Compensation and Diversification of Risk as Fairness Justifications for Limiting Fiduciary Obligations of Corporate Officers, Directors, and Controlling Shareholders, 60 TEMP. L. Q. 47, 52 (1987) ("The premise underlying the neoclassical conclusion is that the securities markets are informationally efficient: available information is imbedded in the prices of securities traded in American stock markets. To the extent that the market anticipates expost incidents affecting the value of a firm at the time of the investment decision, these anticipated incidents are reflected in the price of the firm's securities. Because these anticipated adverse events lower the price of these securities, the investor is compensated, ex ante, for the events."). 
and incorporate the information in the correct way. ${ }^{226}$ Under this conception, "correct" does not necessarily mean it is ultimately accurate; it only needs to accurately reflect the aggregate sentiment concerning the news at the time it is announced. ${ }^{227}$ For example, if a corporation hires a new Chief Executive Officer and the consensus is that he will perform admirably, the stock price should rise if the relevant market is informationally efficient. It does not matter whether the world will learn in two years that the Chief Executive Officer's plans were ill-conceived or that he paid insufficient attention to critical details. That information will be incorporated into the market over time as perceptions change.

Contractarianism also makes a more complex and powerful assertion regarding the fairness of the price paid by investors. Based on tenets of the modern portfolio theory and the capital asset pricing theory, contractarians believe that most investors will eliminate firm-specific risks through their investment strategy, even if shares are not properly priced ex ante. ${ }^{228}$ Portfolio theory contends that investors can minimize risks by purchasing shares of firms that react differently to certain fundamental stimuli, in other words, by diversifying their portfolios. ${ }^{229}$ Further, the type of risk that investors are taking under contractarian theory-the risk that the prospect of a later harm has not been properly priced into a security today-is the type of firm-specific risk that investors can avoid through diversification. ${ }^{230}$ Therefore, contractarians assert that their theory is fair, even if it allows for the waiver of shareholder protections such as fiduciary duties because (1) risks are priced

226 See source cited supra at 221; see also William H. Beaver, Market Efficiency, 56 ACCT. REV. 23,35 $(1981)$ available at http://links.jstor.org/sici?sici=00014826\%28198101\%2956\%3A1\%3C23\%3AME\%3E2.0.CO\%3B2-Q (discussing the theories of market efficiency and stating that "the securities market is said to efficient with respect to some specific information if prices act as if everyone knows the information").

${ }^{227}$ Beaver, supra note 226, at 32.

228 Cox, supra note 225, at 53 ("Modern portfolio theory and capital asset pricing theory suggest that investment in an efficiently diversified portfolio, such as an index fund, will virtually eliminate unsystematic risk.’”.

229 Id. at 54-55 (stating that "it is possible to eliminate unsystematic risk through efficient diversification" and that "[a]n investor who fails to diversify therefore may be subject to uncompensated, unsystematic risk"); see BAINBRIDGE, supra note 209, at 116-19.

${ }^{230} \mathrm{Id}$. at 55, 56 (recognizing that there is a "risk of an incident of ex post harm to an investor [that] may not be reflected in the ex ante price" but stating that "[d]iversification of risk obviates this . . by rendering the risk of detrimental firm-specific ex post events irrelevant to an efficiently diversified investor"). 
2007] What's the Cost of A FreE Pass? A CALl FOR THE RE-AsSESSMENT OF 141 STATUTES THAT ALLOW FOR THE ELIMINATION OF PERSONAL LIABILITY FOR DIRECTORS ex ante into the price of the securities and (2) even if a risk is improperly priced, a well-diversified investor should not be harmed. ${ }^{231}$

\section{Section 102(b)(7) as an Example of Contractarianism}

Delaware's section 102(b)(7) and similar "charter option" statutes are examples of contractarianism in action. ${ }^{232}$ The Delaware legislature had many options following Van Gorkom in 1986. The legislature could have redefined the duty of care, raised the standard of culpability for directors, mandated that personal liability be eliminated, or done nothing. It chose the charter option method, allowing shareholders to take action if they desired. Under this approach, shareholders are free to weigh the benefits of increasing the potential pool of directors, gaining access to more affordable directors' and officers' liability insurance, and shifting the burden of risk to relatively efficient risk bearers ${ }^{233}$ against the risks of providing poor incentives for directors and removing recourse for shareholders who have been wronged.

This type of statute is particularly contractarian because it deals with fiduciary duties, the very element of the corporate contract that traditional scholars are most hesitant to touch. By adopting an exculpatory charter provision allowed by section 102(b)(7), shareholders willingly forego a fundamental protection built into corporate law for over a century and provide directors with more authority at the cost of accountability. However, contractarians continue to assert the fairness of this type of provision.

At least initially, the ability to limit or eliminate liability would be a conscious choice. Shareholders would weigh the benefits of providing this arrangement for members of the board and vote in favor of an exculpatory provision only if the benefits outweigh the detriments. For shareholders who purchase their shares after the provision has been adopted, their interests should be protected in an

231 See supra notes 221, 224-26 and accompanying text.

${ }^{232}$ Henry N. Butler, Smith v. Van Gorkom, Jurisdictional Competition, and the Role of Random Mutations in the Evolution of Corporate Law, 45 WASHBURN L. J. 267, 274 (2006) (noting that "Indiana started the competitive response to Van Gorkom and triggered a nationwide contractarian response-statutes giving corporations the ability to opt-out of Van Gorkom's onerous imposition of liability”).

233 Butler \& Ribstein, supra note 211, at 53 (stating that the benefit of the duty of care "to the corporation is that it deters careless management" but "[t]he cost is that it places a substatnital business risk on managers who, unlike the shareholders, are unable to reduce the risk by diversification and are therefore relatively inefficient risk-bearers"). 
informationally efficient market. The elements of the corporate charter, including the exculpatory provision, should be a known aspect of the corporate contract that is priced ex ante into the investment.

\section{B. Limits of the Contractarian Theory}

In general, the contractarian theory appears sound. It is possible that the only problem is that courts, because of their own conceptions of fairness, are unwilling to enforce this limitation that shareholders have voluntarily placed on themselves. The problems cited in Part II can be solved or addressed by stating: (1) that shareholders paid less for the risk of providing poor incentives for board members, (2) the fact that the statute might be unnecessary is offset by its voluntary nature, and (3) the confusion and unpredictability is the fault of courts who do not apply section 102(b)(7) in the face of what they consider punishable conduct by a corporate board. It is possible that the fault for section 102(b)(7)'s problems lies elsewhere, but that should not be accepted without further examination.

There is also evidence that the contractarian theory, at least in the context of exculpatory provisions, is not as robust an explanation of how corporations actually function as it purports to be. The economic theory underlying contractarianism dictates that strong fiduciary obligations are only desirable to the extent that the cost of enforcement does not exceed the expected benefit. ${ }^{234}$ Thus, the economic theory predicts that firms with a strong form of fiduciary obligation would be priced lower than an otherwise equal firm with a lesser burden on directors. ${ }^{235}$ However, evidence regarding the prices of Delaware firms surrounding the time of the enactment of section 102(b)(7) shows just the opposite effect. ${ }^{236}$ Instead of decreasing after the $V$ an Gorkom decision when many commentators noted that fiduciary obligations were stronger than previously anticipated, ${ }^{237}$ values remained constant. ${ }^{238}$ Even more

${ }^{234}$ Cox, supra note 225 , at 60 (finding that "fiduciary obligations are desirable as standard contractual terms only to the extent that they are justified by a cost-benefit analysis").

${ }^{235} \mathrm{Id}$. ("The neoclassical prediction is that the price of a firm's securities with strong-form fiduciary obligations would decline.”).

236 Bradley \& Schipani, supra note 52, at 48 (finding "that the Trans Union decision had little to no effect on the value of firms incorporated in Delaware," but "that the enactment of section 102(b)(7) is associated with a significant decrease in the equity values of Delaware firms").

237 See sources cited supra note 52.

238 Bradley \& Schipani, supra note 52, at 48 (finding "that the Trans Union decision had little to no effect on the value of firms incorporated in Delaware"). 
2007] What's the Cost of A Free Pass? A CALl For the Re-Assessment OF 143 STATUTES THAT ALLOW FOR THE ELIMINATION OF PERSONAL LIABILITY FOR DIRECTORS

telling is that equity values declined upon the enactment of section 102(b)(7) when the theory predicted they would increase. ${ }^{239}$ These inconsistencies question the validity of the underlying economic assumptions that provide contractarianism with its assertion of fairness. Without a clear claim to fairness, the persuasive power of the theory is diminished.

Another discrepancy exists between the theory's predictions and actual corporate behavior. Because the exculpatory provision is permissive, one would expect to see a wide variety of charter provisions tailored to the specific needs of corporations. Instead, a recent study by Michael Klausner demonstrates that firms usually either include a provision that eliminates liability to the maximum extent permitted by the statute or omit such a provision altogether. ${ }^{240}$ This discrepancy exists both for existing firms that adopted a charter provision upon enactment of a statute and IPO firms that include such a provision prior to their initial offering of securities. ${ }^{241}$ Although it is possible that Delaware happened to strike the perfect balance in its statute causing essentially all firms to adopt uniform provisions, it is more likely that some imperfection is driving these limited choices. ${ }^{242}$

There are at least two explanations as to the source of these imperfections. The first explanation, provided by Klausner, is that learning externalities prohibit shareholders from making optimal choices in deciding to adopt a charter amendment and in finding innovative types of charter amendments to adopt. ${ }^{243}$ The second

239 Id. at 48-49 (finding "that the enactment of section 102(b)(7) is associated with a significant decrease in the equity values of Delaware firms").

${ }^{240}$ Michael D. Klausner, The Contractarian Theory of Corporate Law: A Generation Later, 789-90 (Stanford Law Sch. John M. Olin Program in Law \& Econ. Working Paper No. 334, 2007), available at http://ssrn.com/abstract=957501 (stating that "default rules are uniformly adopted," with the only exception being for "whether to protect management from hostile takeover"). Klausner "examine[s] two phenomena that reflect shortcomings in the contractarian theory:" (1) "corporate governance structures and mechanisms are commonly adopted without contractual commitments to maintain them," and (2) "corporate contracts reflect a high degree of uniformity." Id. at 781, 1782.

${ }^{241} \mathrm{Id}$. at 786 (citing " $\mathrm{r}$ ] ecent empirical work [that] has revealed that incorporation choices at the IPO stage are less diverse than the contractarian theory contemplates").

${ }^{242}$ Id. at 792 (positing two "explanation[s] for uniformity in corporate contracts:" (1) "firms are homogenous with respect to governance matters to which they legally commit, and Delaware default rules suit all firms equally," or (2) "there are market imperfections that impede customization").

${ }^{243} I d$. at 793 (citing "learning externalities" as an explanation for "both Delaware incorporation and the plain vanilla charter"). 
explanation relies on interest group theory. Managers have a strong interest in securing the maximum protection available under law. They are highly motivated to vote and to secure the participation of those who might vote in their favor. In contrast, shareholders who may favor higher accountability of directors, are a diverse group without centralized leadership. It is often a rational choice for shareholders to not participate meaningfully in the formulation of the amendment and in the election securing its passage. ${ }^{24}$ Under these circumstances, it is more likely that an amendment will pass even if it is not in the interests of all shareholders.

The ability of managers and shareholders to structure exculpatory provisions to the maximum benefit of all parties is limited. Because of this limitation, judges are justified in their skepticism of enforcing blanket exculpatory provisions. Klausner provides a possible solution for this dilemma. He suggests that state corporation laws provide "menus of alternative governance structures" so that those forming a firm can choose from several alternatives to customize different aspects of its governance. ${ }^{24}$ Klausner's proposed reform would help overcome the learning externalities by providing choices to potential investors at the incorporation stage.

\section{Proposed Solutions}

The status quo needs improvement. There are a number of possible approaches that shareholders or legislatures may choose to pursue to rectify the current deficiencies. The best solution would be one that addresses the issues raised in this Article without eliminating or reducing shareholder choice. This Part discusses three solutions and comments on the desirability of each.

\section{A. Require Periodic Re-Approval by Shareholders}

One possible solution is for the statute itself to require periodic re-approval by the shareholders of any exculpatory provision. This solution requires state legislatures to amend corporation laws to include a provision requiring that any exculpatory charter provision be re-authorized periodically. The matter could either be revisited at the annual meeting, similar to the election of directors, or it could be addressed less frequently. Corporations already have experience with this type of

${ }^{244}$ Carl Samuel Bjerre, Note, Evaluating the New Director Exculpation Statutes, 73 CORNELL L. REV. 786, 812-13 (1988) (claiming that "[t]he relative absence of shareholder participation actually reflects rational shareholder choice”).

${ }^{245}$ Klausner, supra note 240, at 797 (arguing that "[c]orporate law can . . promote innovation and customization by providing menus of alternative governance structures that firms can adopt in standardized form by designating in their charters that they choose to do so"). 
2007] What's the Cost of a Free Pass? A CALl For the Re-Assessment OF 145 STATUTES THAT ALLOW FOR THE ELIMINATION OF PERSONAL LIABILITY FOR DIRECTORS

requirement. The Internal Revenue Service requires that equity compensation plans be re-approved by shareholders at least every five years. ${ }^{246}$ This system has not proven burdensome and could easily be adopted to exculpatory charter provisions.

This possible solution has several advantages over the current system. First, the uniform approach would impact all corporations equally. By the legislature acting, all shareholders would benefit equally from the action. Second, it would retain the shareholder choice that is the centerpiece of the current system. The critique of contractarianism is not that choice is bad, but rather that there is insufficient evidence that shareholders are fully exercising their theoretical capacity for choice. ${ }^{247}$ Presenting shareholders with an opportunity to affirm their choices reinforces the voluntary nature of the arrangement. Third, a statutory requirement of re-approval is easy to administer. Corporations are already required to hold annual shareholders meetings, and the addition of a single item on the agenda requires minimal expense. Fourth, because the voice of the shareholders would be reaffirmed on a regular basis, courts may be more willing to respect the decision to eliminate liability and dismiss cases that are based on negligent or grossly negligent acts. The difficulty with the current charter option statutes is that there is insufficient evidence that the exculpatory clauses reflect the true wishes of the shareholders. ${ }^{248}$ Periodic re-affirmation overcomes the collective action problems of shareholders who are unable to get the matter onto the ballot themselves. ${ }^{249}$

There is much discussion in academic literature of whether shareholders are rationally apathetic; that is, whether shareholders ignore matters to be voted on and whether that lack of attention is rational in light of their economic interests. The argument is not that the issues on the agenda at a shareholders meeting do not affect shareholder value, because they often do. Rather, the argument is that the resources an average shareholder would need to expend to educate himself on the proposition,

${ }^{246}$ I.R.C. $\ 162(\mathrm{~m})(2007) ; 26$ C.F.R. $\$ 1.162-27(\mathrm{e})(4)(\mathrm{vi})$.

247 See discussion supra Part III.B.

248 Bjerre, supra note 244, at 814 (stating that "even a shareholder who opposes exculpation can rationally retain his ownership and refrain from voting against the charter amendment, if the market mechanisms protect him sufficiently"); Bradley \& Schipani, supra note 53, at 71 (noting that "individuals will 'produce' a finite amount of information, which is to say they will decide to remain rationally ignorant about some things," and applying this insight to investors decisions on voting).

${ }^{249}$ Sale, supra note 72, at 466 (noting that "[s]hareholders [can] vote on the directors' recommendation [to adopt an exculpatory charter provision], but once the provision is adopted, shareholders cannot put it back on the ballot, to, for example, remove it; only the directors can do so"). 
evaluate the options, lobby others to aid in the passage or failure of the particular proposition, and participate in the voting process would exceed the value many shareholders except to receive in return. ${ }^{250}$ If rational apathy is the norm, requiring a periodic vote on provisions that eliminate director liability would have little, if any, impact. There is a danger that this formalistic re-approval would not produce any benefits, but would instead waste corporate time and resources.

Periodic re-approval of exculpatory provisions should produce substantive results and should not fall into the trap of empty formalism, for at least two reasons. First, Institutional Shareholder Services (ISS), an influential group that advises money managers, mutual funds, and other large shareholders on proxy voting matters, recommends voting against a proposal to eliminate personal liability for directors. ${ }^{251}$ This influential recommendation should mean that such a proposal will be highly contested, and corporate managers will need to persuade shareholders to continue to provide this additional protection. Second, even if most corporations reapprove charter amendments, the discussion provoked will be useful. Discussions between management and shareholders often include negotiation and compromise. The opening of this dialogue may provoke the sort of tailored provisions that may limit rather than fully eliminate the liability that the Klausner paper identified as missing from the current landscape.

\section{B. Use Existing Shareholder Proposal System}

A second possible solution is to use the current shareholder proposal system to adopt or repeal exculpatory provisions. Shareholders already have the capacity to place matters on the ballot at the annual meeting under the proxy rules of the Securities and Exchange Commission. ${ }^{252}$ Assuming that all of the procedural guidelines are met, shareholders at a particular company could hold a periodic referendum on the wisdom of its exculpatory charter provision and accomplish something similar to what was proposed above for the legislature to do by statute.

This approach shares most of the benefits of the first option. It retains shareholder choice and is easy to administer. The one advantage it holds over the

250 See Stephen M. Bainbridge, The Case for Limited Shareholder Rights, 53 UCLA L. Rev. 601, 623 (2006).

251 Institutional Shareholder Services (ISS), 2007 ISS Vote Recommendations, Proposal 3i, http://www.issproxy.com/pdf/2007SRI_ISSPolicyComparison.pdf).

${ }^{252}$ Rule 14a-8(b)(1) of the Securities and Exchange Commission requires that any shareholder wishing to place a matter on the ballot must own the lesser of $1 \%$ or $\$ 2000$ worth of an issuer's voting securities for one year prior to submitting a proposal. 17 C.F.R. \240.14a-8(b)(1) (2007). 
2007] What's the Cost of A Free Pass? A CALl For the Re-Assessment OF 147 STATUTES THAT ALLOW FOR THE ELIMINATION OF PERSONAL LIABILITY FOR DIRECTORS legislative response is that shareholders need not wait for a state legislature to act. Any shareholder who meets the minimal requirements may propose to eliminate or to include an exculpatory provision in the corporation's charter.

However, this method is less desirable than amending the statute for a couple of reasons. ${ }^{253}$ First, it is not a uniform approach; therefore, some corporations who do not avail themselves of this approach will continue with the same issues that currently exist. ${ }^{254}$ Second, because shareholders are rationally apathetic to many voting and governance matters, there will be a large, possibly insurmountable, collective action and free-riding problem at most corporations. The proposing shareholder will bear the entire expense for an action that is to benefit everyone. Because of this unequal distribution, many shareholders who might benefit from the proposal may be unwilling to sponsor it themselves.

\section{Repeal Statute-Unsatisfactory Conclusion}

A third possible solution is to repeal the statute altogether. This action would reinstate the duty of care obligation for all directors and reduce the problem of negative incentives and the perceived need to expand the duty of good faith into uncharted territory.

However, there are also several drawbacks to this approach. First, if shareholders want to voluntarily provide the benefit of exculpation to its directors, they should be able to do so. Second, even if the insurance crisis of the mid-1980s was not as severe as perceived, the problem was substantial enough for some rational corporations to determine that they needed to adopt an exculpatory charter provision. For other corporations, a future event may dictate a rational choice to adopt such a provision. Retaining the statute retains flexibility. Third, repealing the statute introduces a new uncertainty. Prior to the enactment of section 102(b)(7), there was debate over whether shareholders of a corporation retain the residual

253 Ramirez, supra note 140, at 354-55 (concluding that "insulating legislation in the form of statutes such as section 102(b)(7) are economically sub-optimal and therefore create pressure for further legal response").

254 Bjerre, supra note 244, at 812 (quoting BERLE \& MEANs, THE MODERN CORPORATION AND PRIVATE PROPERTY, 129 (rev. ed. 1968)) ("The proxy machinery has thus become one of the principal instruments not by which a stockholder exercises power over the management of the enterprise, but by which his power is separated from him.”'). 
power to implement this sort of waiver, even in the absence of a statute. ${ }^{255}$ Section 102(b)(7) mooted that argument, but the question remains. Upon repeal of the statute, any corporation can enact such a provision and contend that it retains the inherent power to do so. This lack of clarity cautions against repeal.

\section{Conclusion}

The Delaware legislature reacted to Smith $v$. Van Gorkom by enacting section 102(b)(7) of the Delaware General Corporation Laws. It was a contractarian response that valued the choice of shareholders to a greater extent than the mandatory rules adopted in other jurisdictions. In the twenty-one years since $V$ an Gorkom, we have learned much, both about the problems associated with section 102(b)(7) and the contractarian theory. Today, there is evidence that section 102(b)(7) provides negative incentives to directors, overcompensates for its original purpose, and creates confusion by elevating the muddled doctrine of the duty of good faith. These problems may be ameliorated by requiring periodic re-approval of any exculpatory charter provision, preferably by amending state corporation statutes, but also by individual shareholder proposals if necessary.

255 Veasey, Finkelstein, \& Bigler, supra note 61, at 403 (recognizing that "[s]ome scholars have suggested that the certificate of incorporation of Delaware corporations could be amended to limit or eliminate liability of directors without enabling legislation under existing law"). 